\title{
THE RELUCTANT PARTNER: MAKING PROCEDURAL LAW FOR INTERNATIONAL CIVIL LITIGATION
}

\author{
STEPHEN B. BURBANK*
}

\section{INTRODUCTION}

In celebrating the one hundredth anniversary of the Hague Conference on Private International Law, we should remember that the United States missed many earlier birthday parties. Moreover, although we have been a member of the Conference since $1964,{ }^{1}$ other members-particularly countries that are also parties to the Hague Service Convention ${ }^{2}$ and the Hague Evidence Convention ${ }^{3}$ - may doubt this country's willingness to abide by the international obligations we have incurred. A recent domestic lawmaking initiative to amend the Federal Rules of Civil Procedure ${ }^{4}$ seems unlikely to dispel our partners' uneasiness, and that can hardly help U.S. efforts to reopen negotiations at the Hague in an area where we do not have the upper hand-the recognition and enforcement of internationally foreign judgments. ${ }^{5}$

The story of U.S. ambivalence about international commitments is not confined to the law of procedure, and it is not a new story. ${ }^{6}$ Proper under-

\section{Copyright $\circledast 1994$ by Stephen B. Burbank}

* Robert G. Fuller, Jr., Professor of Law, University of Pennsylvania.

I have benefited from comments of colleagues in the University of Pennsylvania's Legal Studies Seminar, particularly William Ewald, John Honnold, and Leo Levin, and of Gary Born, on drafts of this article. I am also indebted to Hon. Peter Pfund and Hon. J. Dickson Phillips, Jr., for their comments at the International Symposium. Frank Testa, Class of 1994, University of Pennsylvania Law School, provided excellent research assistance.

1. The United States joined the Hague Conference and the International (Rome) Institute for the Unification of Private Law pursuant to authorization contained in Act of Dec. 30, 1963, Pub. L. No. 88244,77 Stat. 775 . For a description of this country's participation in those and other international organizations, see Peter H. Pfund, United States Participation in Transnational Lawmaking, in LEX MERCATORIA AND ARBITRATION 167 (Thomas E. Carbonneau ed., 1990).

2. Convention on the Service Abroad of Judicial and Extrajudicial Documents in Civil or Commercial Matters, opened for signature Nov. 15, 1965, art. 2, 20 U.S.T. 361, 658 U.N.T.S. 163 [hereinafter Hague Service Convention].

3. Convention on the Taking of Evidence Abroad in Civil or Commercial Matters, opened for signature March 18, 1970, art. 2, 23 U.S.T. 2555, 847 U.N.T.S. 231 [hereinafter Hague Evidence Convention].

4. See infra text accompanying notes 99-179.

5. For a description and analysis of the United States's recent proposal for a convention dealing with the recognition and enforcement of foreign judgments, see Arthur T. von Mehren, Recognition and Enforcement of Foreign Judgments: A New Approach for the Hague Conference?, 57 LAW \& CONTEMP. PROBS. 271 (Summer 1994); Hague Conference on Private International Law, Conclusions of the Working Group Meeting on Enforcement of Judgments (Preliminary Doc. No. 19, Jan. 4, 1993).

6. See, e.g., Harry L. Jones, International Judicial Assistance: Procedural Chaos and a Program for Reform, 62 YALE L.J. 515, 556-59 (1953); Kurt H. Nadelmann, Ignored State Interests: The Federal 
standing of the current situation requires a contextual setting, both historical and institutional. The history of U.S. engagement with procedural problems in international civil litigation is short. Not so the list of institutional actors empowered to make or apply procedural law for international civil litigation in the courts of this country. Indeed, the shortness of the history is related to the length of the list of relevant institutional actors. For years, the supposed requirements of U.S. federalism hindered international lawmaking through private international law treaties ${ }^{7}$ as effectively as they did a federal law of procedure for federal courts. ${ }^{8}$ Although the latter situation changed in the $1930 \mathrm{~s},{ }^{9}$ federalism objections die hard in the international arena.

The states of the United States and their constituent lawmaking institutions remain important actors in international civil litigation in this country. Nonetheless, I leave them largely out of this article. In part, that is a concession to the shortness of life. In addition, this article is about international cooperation and the lawmaking institutions most appropriately involved in its pursuit (or in decisions not to cooperate). The states are powerless to reach international agreements, ${ }^{10}$ and, in areas of federal lawmaking competence, they make law only by federal sufferance. There is federal lawmaking competence on the major procedural issues in international civil litigation, but sufferance may be an appropriate posture. ${ }^{11}$ A decision between state and federal law is appropriately made, however, only after considering the full array of lawmaking techniques. That array is available only at the federal level.

Although my focus is on procedural law and lawmaking for international civil litigation in U.S. courts, it is also important to consider the arrangements we have made, or might in the future make, in aid of litigation abroad. Our record in providing judicial assistance is enviable, but it is a record that continues to haunt us, encouraging Americans to think that no good deed goes unpunished and foreigners to think that, in law as in life, there is no free lunch. ${ }^{12}$

Putting state lawmaking institutions to the side, I am concerned with the history and potential of procedural lawmaking for international civil litigation by means of federal legislation, federal court rulemaking, federal judge-made law, and treaties. After describing and analyzing the previous involvement of

Government and International Efforts to Unify Rules of Private Law, 102 U. PA. L. REV. 323 (1954).

7. See Jones, supra note 6, at 556-58; Nadelmann, supra note 6, at 357-62.

8. See Stephen B. Burbank, The Rules Enabling Act of 1934, 130 U. PA. L. REV. 1015, 1048-94, 1108-12 (1982). The main opponent of the Enabling Act, Senator Thomas Walsh, couched his arguments less in terms of federalism than in terms of convenience to lawyers. Id. at 1111.

9. The Supreme Court promulgated the Federal Rules of Civil Procedure in 1937 (effective in 1938), 308 U.S. 645, 649 (1938), pursuant to the Rules Enabling Act of 1934, Act of June 19, 1934, Pub. L. No. $73-415,48$ Stat. 1064 .

10. "No State shall enter into any Treaty, Alliance, or Confederation . . . " U.S. ConST. art. I, $\S 10$. See Jones, supra note 6, at 561-62.

11. See, e.g., LOUIS Henkin, Foreign AfFairs AND the Constitution 227-48 (1972); Stephen B. Burbank, Federal Judgments Law: Sources of Authority and Sources of Rules, 70 TEX. L. REV. 1551, 1571-87 (1992).

12. See infra text accompanying notes $272-86$. 
these various forms of federal lawmaking in Part II of this article, ${ }^{13}$ I turn in Part III to common threads that run through our lawmaking efforts. ${ }^{14}$ Chief among those threads are unilateralism, a preference for national over international uniformity, impatience, and penuriousness. These related approaches and attitudes have in the past prevented or hindered the process of dialogue and mutual education necessary for international cooperation. I argue that unilateralism deserves to be buried, not reborn, that international uniformity is increasingly more important than national uniformity, and that both international education and education about international and comparative law require more patience and more public resources than we have previously been willing to commit. These conclusions have implications that I explore in Part IV with reference to both domestic and international lawmaking structures and techniques. ${ }^{15}$

\section{II}

\section{LAWMAKING APPROACHES AND INSTITUTIONS IN HistoriCAL CONTEXT}

\section{A. Congressional Legislation}

1. Procedural Legislation in General. Congress has only rarely prescribed the procedural rules to be applied in federal or state courts, including the rules applicable to international civil litigation. Rather, in the case of federal courts, Congress has usually chosen to proceed by delegation, de jure or de facto, and it has rarely disturbed the procedures employed in state courts even in connection with federal statutory rights.

Congress's de jure delegations have come in a series of statutes, dating to the beginning of the Republic, ${ }^{16}$ empowering the federal courts to make local rules of procedure and empowering the Supreme Court to prescribe supervisory or national rules for the lower federal courts. ${ }^{17}$ Its de facto delegations came in a series of statutes (process acts) requiring the federal courts to follow state procedure in civil actions at law. ${ }^{18}$ The two species of delegated power coexisted, at times uneasily, until the Conformity Act of $1872,{ }^{19}$ in which Congress strengthened the federal courts' obligation to follow state procedural

13. See infra text accompanying notes 16-264.

14. See infra text accompanying notes $265-327$.

15. See infra text accompanying notes 328-67.

16. See, e.g., Act of Sept. 24, 1789, ch. 20, $\S 17($ b), 1 Stat. 73,83 ; Act of May 8, 1792, ch. 36, § 2 , 1 Stat. $275,276$.

17. See Paul M. Bator et al., Hart and Wechsler's The Federal Courts and the FEDERAL SYSTEM 749-59 (3d ed. 1988).

18. See id. at 755-59; Burbank, supra note 8, at 1036-39.

Equity had remained free of any requirement of conformity since the beginning of the Republic; it had been governed by court rules promulgated by the Supreme Court since 1822 , and it was preserved against the depredations of code merger (via court rule) by Supreme Court interpretation.

Id. at 1039 (footnotes omitted).

19. Act of June 1,1872 , ch. 255 , $\S 5-6,17$ Stat. $196,197$. 
law, preferring dynamic conformity to state law to the potential mediating power of federal court rules. ${ }^{20}$ A long campaign to reinvigorate the national rulemaking power ensued, culminating in the Rules Enabling Act of 1934 and in the Federal Rules of Civil Procedure, which took effect in 1938. ${ }^{21}$

Throughout the long period prior to the Federal Rules, Congress occasionally departed from its pattern of delegation by enacting statutory provisions regulating particular aspects of federal court procedure. Indeed, the existence of such federal statutes, rendering complete conformity to state law impossible, furnished an arrow in the quiver of those who sought to replace the Conformity Act of 1872 with rulemaking by the Supreme Court. ${ }^{22}$ Very few of Congress's efforts, however, were directed at international civil litigation. ${ }^{23}$ In that area, federal legislation tended to be not only episodic, but also reactive. Thus, outrage that prime suspects in the Teapot Dome scandal were hiding from U.S. justice in Europe prompted legislation to broaden the reach of the subpoena and contempt powers. ${ }^{24}$ The Supreme Court subsequently upheld the statutes as implemented, ${ }^{25}$ but some have questioned whether our legal institutions were not more responsive to a domestic political crisis than they were to the requirements of international law. ${ }^{26}$

In the years after the Federal Rules of Civil Procedure became effective, and until approximately 1975, Congress had additional incentives to stay out of federal court procedure. The desire to rid the books of laws inconsistent with the Federal Rules, which led to the provision in the 1934 Enabling Act known as the supersession clause, ${ }^{27}$ was finally satisfied in the 1948 revision of the Judicial Code. $^{28}$ Thereafter, such federal statutory provisions on court procedure as did creep into law were few and far between.

Since 1975, when Congress transmuted into statute proposed Rules of Evidence that the Supreme Court had promulgated under the Enabling Act, ${ }^{29}$ Congress has become more active in supervising national court rulemaking and

20. See Burbank, supra note 8 , at $1039-40$.

21. See id. at $1040-98$.

22. See id. at $1040-41$.

23. Moreover, the existence of federal legislation did not ensure either that it was known to exist or that it was enthusiastically applied. See Jones, supra note 6, at 540-41; Walter B. Stahr, Discovery Under 28 U.S.C. \$ 1782 for Foreign and International Proceedings, 30 VA. J. INT'L L. 597, 600-02 (1990).

24. See Act of July 3, 1926, ch. 762, 44 Stat. 835-36; Hans Smit, International Aspects of Federal Civil Procedure, 61 Colum. L. REv. 1031, 1044-45 (1961).

25. See Blackmer v. United States. 284 U.S. 421 (1931).

26. See Smit, supra note 24, at 1045-49.

27. Section 1 of the 1934 Rules Enabling Act provided in pertinent part: "[Said rules] shall take effect six months after their promulgation, and thereafter, all laws in conflict therewith shall be of no further force or effect." Act of June 19, 1934, Pub. L. No. 73-415, 48 Stat. 1064. For the history of this provision, see Burbank, supra note 8, at 1052-54. For recent attempts to delete the supersession clause, see Stephen B. Burbank, Hold the Corks: A Comment on Paul Carrington's "Substance" and "Procedure" in the Rules Enabling Act, 1989 DUKE L.J. 1012, 1036-46.

28. See Burbank, supra note 27, at 1043-44.

29. Act of Jan. 2, 1975, Pub. L. No. 93-595, 88 Stat. 1926. In fact, the process started two years earlier, when Congress enacted a statute providing that the proposed rules not be effective unless expressly approved by Congress. Act of March 30,1973, Pub. L. No. 93-12, 87 Stat. 9. 
in independently framing rules for federal court litigation. ${ }^{30}$ A comprehensive overhaul in 1988 of the statutes empowering the federal courts to make local and national rules ${ }^{31}$ was animated in part by the hope that Congress might again assume a passive role. ${ }^{32}$ So long, however, as the alleged costs and delays of litigation are an overtly political issue, ${ }^{33}$ that seems unlikely, as does the prospect that ambitious politicians will be persuaded to leave all of the reform initiative with the federal rulemakers. ${ }^{34}$

\section{The Commission and Advisory Committee on International Rules of Judicial}

Procedure. A major exception to Congress's hands-off attitude towards federal procedural law in the period between 1938 and 1975 occurred precisely in the area of international civil litigation. In 1964, Congress enacted a number of provisions relating to international judicial assistance. ${ }^{35}$ A closer look at the process by which the 1964 legislation was formulated is important to an understanding of policies and attitudes with respect to, and institutional structures for, lawmaking in international civil litigation.

Following World War II, U.S. lawyers engaged in international transactions became increasingly concerned that adequate mechanisms did not exist for judicial assistance (including service of process, taking evidence abroad, and proof of foreign law) in international civil litigation in our courts. It also became apparent that those involved in litigation abroad had some of the same problems with respect to assistance from the United States. ${ }^{36}$ From at least 1950, therefore, various bar groups sought to move the United States to international cooperation. ${ }^{37}$ Finally, in 1958, Congress established a Commission and Advisory Committee on International Rules of Judicial Procedure. ${ }^{38}$ It defined the purposes of the Commission as follows:

SEC. 2. The Commission shall investigate and study existing practices of judicial assistance and cooperation between the United States and foreign countries with a view to achieving improvements. To the end that procedures necessary or incidental

30. See H.R. REP. No. 422, 99th Cong., 1st Sess. 4-5, 8-9, 12-14 (1985) [hereinafter 1985 House REPORT].

31. Act of Nov. 19, 1988, Pub. L. No. 100-702, $\S \S 401-407,102$ Stat. 4648-52 (amending 28 U.S.C. $\S \S 2071-74)$.

32. See 1985 HOUSE REPORT, supra note 30, at 16, 22; Burbank, supra note 27, at 1043. The 1985 House Report was specifically incorporated by reference into the legislative history of the 1988 statute. H.R. REP. No. 889, 100th Cong., 2d Sess. 26 (1988).

33. See, e.g., Deborah R. Hensler, Taking Aim at the American Legal System: The Council on Competitiveness's Agenda for Legal Reform, 75 JUDICATURE 244 (1992).

34. See, e.g., Civil Justice Reform Act of 1990, Pub. L. No. 101-650, $\S \S 101-105,104$ Stat. 5089-98 (codified at 28 U.S.C. \$\$ 471-82); Stephen B. Burbank, Ignorance and Procedural Law Reform: A Call for a Moratorium, 59 BROOKLYN L. REV. 841 (1993); Linda S. Mullenix, The Counter-Reformation in Procedural Justice, 77 MINN. L. REv. 375 (1992). For a somewhat dated account of the role of the Judicial Conference of the United States in federal legislation affecting the judiciary, see PETER G. Fish, THE POLITICS OF FEDERAL JUdicial AdMINISTRATION 301-39 (1973).

35. Act of Oct. 3, 1964, Pub. L. No. 88-619, 78 Stat. 995.

36. See Jones, supra note 6 , at 515-17, 558-59.

37. See id. at 558-59; Harry L. Jones, International Judicial Procedures, in 1954 PROC. INT'L BAR Ass'N 83, 94-97 (1956); Resolution Concerning Negotiation of Treaties of Judicial Assistance, 1951 PROC. AM. SOC'Y INT'L L. 188-90.

38. Act of Sept. 2, 1958, Pub. L. No. 85-906, 72 Stat. 1743. 
to the conduct and settlement of litigation in State and Federal courts and quasijudicial agencies which involve the performance of acts in foreign territory, such as the service of judicial documents, the obtaining of evidence, and the proof of foreign law, may be more readily ascertainable, efficient, economical, and expeditious, and that the procedures of our State and Federal tribunals for the rendering of assistance to foreign courts and quasi-judicial agencies be similarly improved, the Commission shall-

(a) draft for the assistance of the Secretary of State international agreements to be negotiated by him;

(b) draft and recommend to the President any necessary legislation;

(c) recommend to the President such other action as may appear advisable to improve and codify international practice in civil, criminal, and administrative proceedings; and

(d) perform such other related duties as the President may assign. ${ }^{39}$

Unfortunately, the Commission and its Advisory Committee labored under serious disabilities from the start. Established in late 1958, they were required to finish their work and submit a final report by the close of $1959 .^{40} \mathrm{Had}$ that even been possible, Congress failed to appropriate funds in 1958 or the first quarter of $1959,,^{41}$ although the statute had authorized an appropriation of as much as $\$ 75,000 .^{42}$

The Commission overcame the first problem, securing three successive extensions of its existence, so that it was finally authorized to operate until December $31,1966 .{ }^{43}$ But it never succeeded in prying from the Treasury the funds necessary for the ambitious work expected of it. Subsisting at first on a $\$ 25,000$ loan from the President $(\$ 9,000$ of which could not be used because it was not spent or obligated in 1959), ${ }^{44}$ the Commission received only $\$ 60,000$ in funds appropriated for its work over its lifetime. ${ }^{45}$ Even that figure is deceptive, because the last appropriation, $\$ 25,000$ in legislation effective April 30,1965 , was available only until May $1,1965^{46}$ and was intended partially to reimburse Commission staff who had been working without salary, and otherwise expending their own funds, for more than two years. ${ }^{47}$

In these circumstances, it should be no surprise that, as Professor Nadelmann critically observed, ${ }^{48}$ the Commission never got around to the primary task set for it in the enabling legislation: "draft[ing] for the assistance of the Secretary of State international agreements to be negotiated by him." 49 The surprise is

39. Id. $\S 2,72$ Stat. at 1743 .

40. Id. $\S 7(\mathrm{~b}), 72$ Stat. at 1745 .

41. Act of May 20, 1959, Pub. L. No. 86-30, 73 Stat. 33, 43.

42. Act of Sept. 2, 1958, Pub. L. No. 85-906, \& 8, 72 Stat. 1743, 1745.

43. See Act of Sept. 16, 1959, Pub. L. No. 86-287, 73 Stat. 567 (extending Commission's life until December 31, 1961); Act of Sept. 26, 1961, Pub. L. No. 87-324, 75 Stat. 685 (until December 31, 1963); Act of Aug. 30, 1964, Pub. L. No. 88-522, 78 Stat. 700 (until December 31, 1966).

44. See First Annual Report of the Commission on International Rules of Judicial Procedure 17 (1960) [hereinafter First Annual Report].

45. Act of May 20, 1959, Pub. L. No. 86-30, 73 Stat. 33, 43 (\$25,000); Act of May 17, 1963, Pub. L. No. 88-25, 77 Stat. 20, 26 (\$10,000); Act of Aug. 30, 1964, Pub. L. No. 89-16, 79 Stat. 81, $91(\$ 25,000)$.

46. Act of Apr. 30, 1965, Pub. L. No. 89-16, 79 Stat. 81, 91.

47. See 111 CONG. REC. 8532-33 (1965).

48. See Kurt H. Nadelmann, The United States Joins the Hague Conference on Private International Law, 30 LAw \& CoNTEMP. Probs. 291, 309, 323 (Spring 1965) [hereinafter Hague Conference].

49. Act of Sept. 2, 1958, Pub. L. No. 85-906, § 2, 72 Stat. 1743, quoted in full, supra text accompanying note 39 . 
rather that the Commission and Advisory Committee accomplished anything consequential. Indeed, Professor Nadelmann seems to have doubted that those bodies deserved much credit for reforms that issued under their auspices, including the legislation passed by Congress in $1964 .^{50}$

In 1959, when it was unclear whether the Commission's life would be extended and when it was quite clear that the funds for its work were wholly inadequate, ${ }^{51}$ the Advisory Committee recommended, and the Commission approved, an initial program giving priority "to projects which will be of most benefit to courts and litigants in this country, and which offer a chance of substantial accomplishment within the period of the statutory life of the Commission," treating projects that would require several years for full treatment "on a 'pilot' basis," and confining "work to projects which will not require international agreements or treaties and the consequent negotiation with foreign governments by the Department of State." 52 One approved project called for "a study of the relevant provisions of the United States Code and of the Federal Rules of Civil Procedure and the Federal Rules of Criminal Procedure and draft[ing] proposals for amendments, if necessary." 53

Notwithstanding a $\$ 25,000$ appropriation in $1959,{ }^{54}$ the Commission would have needed private funding for even the scaled-down work program adopted in that year. And that is what, with the President's approval, ${ }^{55}$ the Commission sought, securing an arrangement with the Carnegie Corporation and Columbia Law School "whereby funds would be made available through a research project of the Columbia Law School to finance the work of the Commission." According to that arrangement, Columbia would employ the Commission's Director and staff as consultants, the Columbia Project on International Procedure would "make available to the Commission the fruits of its research and study of existing practices of judicial assistance," and leaders of the Commission (and Advisory Committee) and of the Columbia Project would cooperatively determine "the manner in which research conducted for the benefit of the Commission [would] be undertaken." 57

The fruits of this collaboration included the legislation that is my immediate concern, as well as amendments to the Federal Rules of Civil Procedure and a

50. See Nadelmann, Hague Conference, supra note 48, at 323 ("[A]n individual law school beneficiary of a Foundation grant was largely in control of the work, while on the Commission membership changed with changing administrations.") (footnote omitted).

51. See supra text accompanying notes $40-47$.

52. First Annual Report, supra note 44, at 18; see id. at 21. The program was "for the ensuing two years." Id. at 5. See also H.R. ReP. No. 801, 86th Cong., 1st Sess. 3 (1959) ("more limited program ... which would afford measurable results within the period of the requested extension").

53. First Annual Report, supra note 44, at 19.

54. See supra note 45.

55. See Second Annual Report of the Commission on International Rules of Judicial Procedure 2 (1961) [hereinafter Second Annual Report].

56. Id.

57. Id. at 3 . 
uniform act. ${ }^{58}$ When the Carnegie grant to Columbia expired at the end of $1962,{ }^{59}$ the Commission could accomplish little further without appropriated or other funds. $^{60}$ Notwithstanding pleas that the Commission's most important work-laying the groundwork for international agreements-remained to be done, Congress was unmoved. ${ }^{61}$

The legislation recommended by the Commission and passed by Congress in 1964 dealt with aspects of judicial assistance in aid of both domestic and foreign proceedings. Among its provisions were new sections or amendments to existing law designed to facilitate proof of foreign documents in criminal and civil actions, ${ }^{62}$ empowering the State Department to receive and transmit letters rogatory, ${ }^{63}$ and empowering district courts to assist in serving documents "in connection with a proceeding in a foreign or international tribunal" in securing testimony and documents for use abroad. ${ }^{65}$ In language essentially identical to that used by the Commission's chair when transmitting the proposed bill, the Senate Judiciary Committee observed:
Until recently, the United States has not engaged itself fully in efforts to improve practices of international cooperation in litigation. The steadily growing involvement of the United States in international intercourse and the resulting increase in litigation with international aspects have demonstrated the necessity for statutory improvements and other devices to facilitate the conduct of such litigation. Enactment of the bill into law will constitute a major step in bringing the United States to the forefront of nations adjusting their procedures to those of sister nations and thereby providing equitable and efficacious procedures for the benefit of tribunals and litigants involved in litigation with international aspects.
It is hoped that the initiative taken by the United States in improving its procedures will invite foreign countries similarly to adjust their procedures. ${ }^{66}$

In light of Congress's shabby treatment of the Commission, ${ }^{67}$ it would be a mistake to read too much into the 1964 legislation, let alone to see in that legislation an exception for international cases to Congress's traditional inertia with respect to matters of procedure. ${ }^{68}$ Yet, notwithstanding Professor

58. See Fourth Annual Report of the Commission on International Rules of Judicial Procedure, reprinted in H.R. DoC. No. 88, 88th Cong., 1st Sess. 7-8 (1963) [hereinafter Fourth Annual Report].

59. See id. at 13 .

60. See supra text accompanying notes 44-47.

61. See Fourth Annual Report, supra note 58, at 8-14; H.R. REP. No. 1051, 88th Cong., 1st Sess. 2, 4 (1963); 111 CONG. REC. 8530-33 (1965); see also infra text accompanying note 313.

62. See Act of Oct. 3, 1964, Pub. L. No. 88-619, \& 2, 78 Stat. at 995 (amending 18 U.S.C. \& 3491); id. $\S 5$ (a), 78 Stat. at 996 (amending 28 U.S.C. $\S 1741$ ); id. $\S 7(\mathrm{a}), 78$ Stat. at 996 (amending 28 U.S.C. $\S 1745)$.

63. See id. $\S 8($ a), 78 Stat. at $996-97$ (amending 28 U.S.C. $\S 1781$ ).

64. Id. $\$ 4(\mathrm{a}), 78$ Stat. at 995 (adding 28 U.S.C. $\$ 1696$ ).

65. See id. $\S 9$ (a), 78 Stat. at 997 (amending 28 U.S.C. $\$ 1782$ ).

66. S. REP. No. 1580, 88th Cong., 2d Sess. 2 (1964). Compare with id. at 13 (letter from Oscar Cox, Chairman, to Hon. John W. MacCormack, May 28, 1965). See also H.R. REP. No. 1052, 88th Cong., 1st Sess. 3, 4 (1964).

67. See supra text accompanying notes 40-47, 59-61; infra text accompanying note 313 .

68. In connection with the amendment of 28 U.S.C. $\S 1782$, two commentators have noted: Congress played no role in redrafting the statute. Rather, the new draft was written entirely by an advisory committee and adopted summarily. Instead of reviewing the bill for substantive accuracy, Congress merely adopted the drafters' report as legislative history. 
Nadelmann's suggestion to the contrary, ${ }^{69}$ the legislation recommended by the Commission (as well as the rest of its work) appears to have been the product of a truly collaborative effort among the Commission, its Advisory Committee, and the Columbia Project. ${ }^{70}$ Ironically, in light of the policies animating the Commission's stated program, ${ }^{71}$ the legislation gave more to foreign litigants and tribunals in need of judicial assistance than it did to domestic litigants and tribunals. Other changes in domestic law stimulated by the Commission, which were brought to Congress's attention, redressed the imbalance to some extent. $^{72}$ The imbalance may not have mattered, however, because both the executive branch and the private sector supported the proposed legislation, ${ }^{73}$ moreover, the legislation was not controversial, and it issued from a representative body established by Congress, and advised, as Congress directed, by a distinguished committee of experts.

Whoever deserves credit (or blame) for the 1964 legislation enlarging the powers of our courts and State Department to provide and secure assistance in aid of international litigation, the legislation has affected this country's subsequent efforts to fashion arrangements for international civil litigation satisfactory to us and to other countries.

\section{B. Federal Court Rulemaking}

1. The Original Federal Rules of Civil Procedure. The original Federal Rules of Civil Procedure contained very few special provisions for international civil litigation. ${ }^{74}$ This is not surprising, as the great increase in international civil litigation came after World War II. ${ }^{75}$ It is also not surprising because a major goal of the 1934 Enabling Act was uniformity among federal district courts. ${ }^{76}$ The rulemakers pursued that goal by fashioning rules that were not only uniform in that sense but also trans-substantive, that is, uniformly applicable to

Brian E. Bomstein \& Julie M. Levitt, Note, Much Ado About 1782: A Look at Recent Problems with Discovery in the United States for Use in Foreign Litigation Under 28 U.S.C. \$ 1782, 20 U. MIAMI INTER-AM. L. REV. 429, 439 (1989) (footnotes omitted).

69. See supra note 50 and accompanying text.

70. See Second Annual Report, supra note 55, at 3-9; Third Annual Report of the Commission on International Rules of Judicial Procedure 3-9 (1962) [hereinafter Third Annual Report].

71. See supra text accompanying note 52.

72. See Hans Smit, International Litigation Under the United States Code, 65 COLUM. L. REV. 1015, 1035 (1965); infra text accompanying notes 90-95. For the Commission's role in the 1963 and 1966 amendments to the Federal Rules of Civil Procedure, see infra text accompanying notes 80-85. Rule 4(i) "was part of an integrated package, some of which was passed by Congress and signed by the President, and all of which was specifically brought to Congress's attention." Stephen B. Burbank, The World in Our Courts, 89 MICH. L. REV. 1456, 1484 (1991) (footnote omitted) (book review).

73. See H.R. REP. No. 1052, 88th Cong., 1st Sess. 3 (1964).

74. See 308 U.S. 645, 700 (1938) (FED. R. CIV. P. 28(b)); id. at 712-13 (FED. R. CIV. P. 37(e)); id. at 719-20 (Fed. R. Civ. P. 44(a)); id. at 722 (FED. R. Civ. P. 45 (e)(2)).

75. See Benjamin Kaplan, Amendments of the Federal Rules of Civil Procedure, 1961-1963 (I), 77 HARV. L. REV. 601, 635 (1964); supra text accompanying note 36.

76. See S. REP. No. 1174, 69th Cong., 1st Sess. 1 (1926); Burbank, supra note 8, at 1050-98; Stephen B. Burbank, The Transformation of American Civil Procedure: The Example of Rule 11, 137 U. PA. L. REV. 1925, 1929 (1989). 
every type of civil action in the federal courts. ${ }^{77}$ Separate (or different) provisions for international civil litigation would have derogated from this scheme.

2. The 1963 Amendments. Those concerned about the inadequacy of our mechanisms for seeking and providing assistance in aid of international civil litigation recognized that some provisions in the Federal Rules on such matters as service were an invitation to disaster for litigants using them abroad, whether immediately or when it came time to enforce a judgment. ${ }^{78}$ They also recognized that the few provisions in the Rules specifically treating litigation with international aspects failed to capture either the reality of foreign law and practice, or the potential for effective judicial assistance, or both. ${ }^{79}$

As we have seen, even before the Commission on International Rules of Judicial Procedure and its Advisory Committee linked up with the Columbia Project on International Procedure, the Commission had decided, as one of its initial projects, to consider revisions in federal statutes and rules. ${ }^{80}$ Targeted for study in the Commission's First Annual Report were Federal Rules of Civil Procedure 4, 28, 29, and $44 .{ }^{81}$ Once the collaboration with the Columbia Project was established, "it was decided that the staffs of both the Commission and the Columbia Project should undertake on a priority basis a study of desirable changes in the Federal Rules of Civil Procedure and in Federal statutes." ${ }^{82}$ In connection with that stated priority, the Commission's Second Annual Report noted that a member of the Advisory Committee, Judge Albert Maris, was also chair of the Judicial Conference Committee charged with recommending amendments to the Federal Rules. ${ }^{83}$ It also reported that "[a]rrangements for cooperation" 84 had been made with the reporters of the relevant rules committees.

This collaboration yielded the addition of Rule 4(i) ("Alternative Provisions for Service in a Foreign Country") and amendments to Rule 28(b) ("Persons Before Whom Depositions May Be Taken") in 1963, and amendments to Rule 44 ("Proof of Official Record") and the addition of Rule 44.1 ("Determination of Foreign Law") in 1966. ${ }^{85}$ The 1963 amendments sought to provide litigants

77. See Burbank, supra note 76, at 1934-35. The major exceptions were Rules 64 and 69 , dealing with provisional and final remedies, both of which require reference to state law. For the reasons, see Burbank, supra note 8, at 1145-47.

78. See First Annual Report, supra note 44, at 12, 19; Jones, supra note 6, at 534-37; Kaplan, supra note 75, at 635 ; Smit, supra note 72 , at $1032-43$.

79. See Ronan E. Degnan, Obtaining Witnesses and Documents (or Things), 108 F.R.D. 223, 226-27 (1986); Jones, supra note 6, at 517-22; Smit, supra note 24, at 1053-59.

80. See supra text accompanying note 53 .

81. First Annual Report, supra note 44, at 19.

82. Second Annual Report, supra note 55, at 3.

83. Id.

84. Id. at 7. See also Third Annual Report, supra note 70, at 4 (Commission's drafting subcommittee "maintains a liaison with" the Civil Rules Advisory Committee).

85. See Fourth Annual Report, supra note 58, at 55-70; 374 U.S. 861, 877-78 (1963) (FED. R. CIV. P. 4(i)); id. at 883-84 (FED. R. CIV. P. 28(b)); 383 U.S. 1029, 1053-54 (1966) (FED. R. CIV. P. 44); id. at 1055 (FED. R. CIV. P. 44.1). 
in our courts with greater flexibility in serving process and taking evidence abroad.

The Advisory Committee Note to Rule 4(i) pointed out that "[s]ervice abroad may be considered by a foreign country to require the performance of judicial, and therefore 'sovereign,' acts within its territory, which that country may conceive to be offensive to its policy or contrary to its law." noted the risk that service in violation of foreign law might render a judgment unenforceable in that country or even lead to sanctions against the process server ${ }^{87}$ The provision itself, however, merely presented an array of alternatives in addition to those available under other sections of Rule 4. A lawyer unfamiliar with the pitfalls of foreign service would thus have needed to be aware of the note in order for the rule usefully to "clarify the provisions governing service upon parties in foreign countries." 88 Moreover, according to a 1992 decision by the United States Court of Appeals for the Third Circuit, a federal district court was powerless to direct, although presumably it could seek to influence, a litigant to use a particular alternative. ${ }^{89}$

By (1) permitting service in violation of foreign law (and, in the view of some countries, of international law), ${ }^{90}$ (2) failing adequately to assist lawyers in making an informed choice among alternatives, and (3) neglecting to empower the courts to require resort to another alternative when that would benefit international relations, Rule 4(i) hardly reflected "due regard for the sensibilities of foreign governments." 91 Rather, just as many of the 1964 legislative amendments represented a unilateral grant of judicial assistance in aid of litigation abroad,$^{92}$ Rule 4(i) represented a unilateral assertion of power in aid of litigation in the federal courts, affording great flexibility but not requiring deference to foreign law or consideration of the international implications of service. Indeed, although the reporter of the 1963 amendments acknowledged that this country should "show some initiative in the international 'unification' of private law in which we have been notably laggard," ${ }^{, 3}$ he argued that "it would be quixotic to remit the problem of foreign service to a solution which could be attained, if it is attainable at all, only over a period of many years." $\mathrm{He}$ also opined that "[t]he adoption of rule 4(i) need not inhibit efforts to achieve international arrangements if the goal is thought worthy of the effort." ${ }^{\circ 5}$

86. 2 Moore's Federal Practice II 4.01[25], at 4-35 (2d ed. 1976) (Fed. R. Civ. P. 4(i) advisory committee note).

87. See id.

88. Id.

89. See Umbenhauer v. Woog, 969 F.2d 25, 30 (3d Cir. 1992).

90. See Burbank, supra note 72 , at 1476-77, 1483. Cf. id. at 1490 (taking evidence abroad).

91. Smit, supra note 72, at 1018; see Burbank, supra note 72, at 1483.

92. See supra text accompanying notes 71-72.

93. Kaplan, supra note 75 , at 636 (footnote omitted).

94. Id.

95. Id. (emphasis added). A suggestion of doubt on that score is curious given Congress's stated priorities in establishing the Commission and Advisory Committee on International Rules of Judicial Procedure. See supra text accompanying note 39. 
Whatever their defects and impact on subsequent international lawmaking, the 1963 amendments to the Federal Rules were the product of collaboration between a statutory Commission and Advisory Committee and those assisting the Supreme Court in the formulation of national court rules under the Enabling Act. Moreover, although the Enabling Act did not then, and does not now, either require congressional approval or contemplate review by the executive branch before Federal Rules become effective, ${ }^{96}$ the Commission brought the existence of these proposals to the attention of both. ${ }^{97}$ Finally, whatever gaps there may have been in the rulemakers' knowledge of, or experience in, international civil litigation or foreign law, the Commission and its Advisory Committee, as well as the leadership of the Columbia Project, included a number of individuals who, by training or experience, were experts in the area. ${ }^{98}$

3. Recent proposals to amend the Federal Rules. The rulemakers have recently returned to consideration of the needs of international civil litigation, prompted in part by this country's adherence to the Service and Evidence Conventions in the years since the Judicial Code and the Federal Rules were amended unilaterally to provide greater judicial assistance in cases having international aspects. Their efforts have been controversial and hence protracted. ${ }^{99}$ The British government protested proposed amendments to Rules 4, 26, and 28 when they were before the Supreme Court, ${ }^{100}$ and the Court took the unusual step of sending the proposals back for further consideration. ${ }^{101}$ The controversy continued, resulting in a decision by the Judicial Conference's Standing Committee to delete one of the products of the Advisory Committee's reconsideration, a proposed amendment to Rule $26 .{ }^{102}$ Rule 4 underwent lastminute surgery. Although the amendments became effective, it remains to be seen whether the operation was successful. ${ }^{103}$

96. See 28 U.S.C. $\S \S 2072,2074$ (1988); Burbank, supra note 8, at 1102, 1177-79, 1196 n.779; Burbank, supra note 72 , at 1483 .

97. See supra text accompanying note 72 .

98. See Fourth Annual Report, supra note 58, at ix-xvi (listing members and former members of the Commission and Advisory Committee).

99. For discussion and criticism of the Advisory Committee's proposals to amend Rules 4 and 26 as of May 1991, see Burbank, supra note 72, at 1484-90, 1494-96.

100. See United Kingdom Embassy Note No. 63, transmitted by letter from Hon. Edwin D Williamson, Legal Adviser, Department of State, to Hon. William H. Rehnquist, Chief Justice of the United States (April 19,1991) [hereinafter United Kingdom Embassy Note] (copy on file with author).

101. Letter from William K. Suter, Clerk of the Supreme Court, to L. Ralph Meecham, Secretary of the Judicial Conference (Dec. 11, 1991) (returning proposed amendments to Rules 4, 4.1, 12, 26, 28, 30, and 71 A and enclosing Williamson letter and United Kingdom Embassy Note, supra note 100) (copy on file with author). See also H.R. Doc. No. 102-77, 102d Cong., 1st Sess. III (1991) (Letter from Hon. William H. Rehnquist, Chief Justice of the United States, to Hon. Thomas S. Foley, Speaker, United States House of Representatives (April 30, 1991)) [hereinafter HOUSE DOC.].

102. See Report of the Judicial Conference Committee on Rules of Practice and Procedure 8 n.1 (Agenda E-19, September 1992) [hereinafter Standing Committee Report] (copy on file with author). This action obviated the objection to the proposed amendment to Rule 28(b). See United Kingdom Embassy Note, supra note 100.

103. See infra text accompanying notes $114-18,128$. 
Criticism of the proposed amendments to Rule 4 centered on two provisions, one that, as originally approved by the Standing Committee after reconsideration, would have extended a proposed waiver of service mechanism (with cost sanctions if a defendant refused to waive service without good cause) to situations in which service had to be made in a foreign country, ${ }^{104}$ and the other including as an alternative for service upon individuals in a foreign country "other means not prohibited by international agreement as may be directed by the court." 105

a. Waiver of service. As to the waiver of service mechanism, it was objected that, if extended abroad, it would violate the policy of some foreign governments prohibiting waivers, that it would infringe upon foreign sovereignty, that a waiver made in the face of a cost sanction is not consensual, and that the provision would violate the Service Convention, at least if implemented in a country that was a party to that treaty and that did not approve service by mail. ${ }^{106}$ The Advisory Committee attempted to meet such objections, asserting:

It is hoped that, since transmission of the notice and waiver forms is a private nonjudicial act, does not purport to effect service, and is not accompanied by any summons or directive from a court, use of the procedure will not offend foreign sovereignties, even those that have withheld their assent to formal service by mail or have objected to the "service-by-mail" provisions of the former rule. Unless the addressee consents, receipt of the request under the revised rule does not give rise to any obligation to answer the lawsuit, does not provide a basis for default judgment, and does not suspend the statute of limitations in those states where the period continues to run until service. The only adverse consequence to the foreign defendant is one shared by domestic defendants; namely, the potential imposition of costs of service that, if successful in the litigation, it would not otherwise have to bear. However, this shifting of expense would not be proper under the rule if the foreign defendant's refusal to waive service was based upon a policy of its government prohibiting all waivers of service. ${ }^{107}$

The Advisory Committee also stressed the "distinct advantages"108 of waiver for a foreign defendant and attempted to meet the specific objections of the British government by asserting that "there will be little reason for a plaintiff" 109 to use the waiver mechanism, rather than formal service under the Hague Convention, in countries like the United Kingdom. Finally, the Committee also indicated that good cause not to shift costs would exist if a defendant refusing to waive "was located in a foreign country whose laws or

104. See Proposed Rule 4(d), Proposed Amendments to the Federal Rules of Civil Procedure and Forms Submitted to the Judicial Conference of the United States by Standing Committee on Rules of Practice and Procedure 6-9 (Agenda E-19, September 1992) [hereinafter Standing Committee Proposals] (copy on file with author).

105. Proposed Rule 4(f)(3), Standing Committee Proposals, supra note 104, at 12.

106. See Burbank, supra note 72, at 1485-86; Comments on Proposed Amendments to the Federal Rules of Civil Procedure: Proposed Revisions to Rule 4(d) (Service of Process on Individuals in Foreign States) and to Rule 26(a)(5) (Extraterritorial Discovery) 2-3, transmitted by letter from Hon. Stuart M. Gerson, Assistant U.S. Attorney General, to Joseph F. Spaniol, Secretary, Committee on Rules of Practice and Procedure (April 6, 1992) [hereinafter Executive Branch Comments] (copy on file with author); United Kingdom Embassy Note, supra note 100.

107. Standing Committee Proposals, supra note 104, at 28.

108. Id.

109. Id. at 29. 
policies prohibited its residents from waiving service of formal judicial process even from its own courts." 110

It is heartening to see the change in tone that has marked successive versions of the Advisory Committee's attempt to justify the extension of waiver of service to defendants abroad. Such a change is evident in language stressing the advantages that the opportunity for waiver may hold for a foreign defendant. Perhaps more important, the Committee's Note has become more conciliatory, no longer confidently asserting that the proposed Rule should not offend reasonable foreign governments, ${ }^{111}$ which was the tone of those responsible for the 1963 amendments. ${ }^{112}$ Of course, in the meantime the rulemakers had learned how some foreign governments in fact reacted to their proposal. ${ }^{13}$

Even more heartening is the last-minute and extraordinary decision of the Standing Committee ${ }^{114}$ to reverse itself and to recommend that the Judicial Conference approve an alternative version of Rule 4 that made cost-shifting for refusal to waive service applicable only if the plaintiff and defendant are both located in the United States. ${ }^{115}$ The decision was extraordinary because it followed the meeting of the full Committee at which the extension of costshifting to defendants located in foreign countries was approved over dissents, ${ }^{116}$ and because it was a direct result of a subsequent meeting (in September 1992) of the Chairs of the Advisory and Standing Committees with representatives of the Departments of State and Justice and of the British Embassy. ${ }^{117}$ The Judicial Conference accepted the revised recommendation,

110. Id. at 30 (emphasis added). Passing what it means for a foreign government to "prohibit" waiver of service, the Advisory Committee would have required that the prohibition extend to all cases, including those that were wholly domestic. The notion seems to have been that a government policy prohibiting only waivers sought in litigation abroad did not count. That is a notion as puzzling as the argument, advanced in connection with the reform proposals of thirty years ago, that treated as specious foreign objections to the unilateral acts of other countries when those same acts were permitted by treaty. See Burbank, supra note 72 , at 1486 n.177.

111. The Advisory Committee Note to the proposed amendment to Rule 4 that was submitted to, and returned by, the Supreme Court asserted that "[b]ecause the transmission of the waiver does not purport to effect service except by consent, the transmission of a request for consent sent to a foreign country gives no reasonable offense to foreign sovereignty, even to foreign governments that have withheld their assent to service by mail." Proposed Amendments to the Federal Rules of Civil Procedure 30 (1990) (emphasis added), quoted in Burbank, supra note 72, at 1485 . For the full text of the proposed rule and note, see HOUSE DOC., supra note 101, at 61-102.

112. See Kaplan, supra note 75 , at 637 ; Smit, supra note 72 , at 1018 . For criticism of that tone, see Burbank, supra note 72, at 1486; Nadelmann, supra note 48, at 310-11 n.141.

113. See supra text accompanying note 100 .

114. See letter from Hon. Robert E. Keeton, Chairman, Committee on Rules of Practice and Procedure, to Hon. Stuart M. Gerson, Assistant U.S. Attorney General (Oct. 6, 1992) [hereinafter Keeton Letter] (copy on file with author).

115. Proposed Amendments to the Federal Rules of Civil Procedure and Forms 8-9 (Nov. 27, 1992) [hereinafter Judicial Conference Proposals] (copy on file with author). Cost-shifting applies only if "a defendant located within the United States fails to comply with a request for waiver made by a plaintiff located within the United States." Id. at 8.

116. See Standing Committee Report, supra note 102, at 8 n.2.

117. See Keeton Letter, supra note 114. 
which was subsequently promulgated by the Supreme Court and went into effect on December 1, 1993. ${ }^{118}$

Changes in tone and the deletion of cost-shifting when either the plaintiff or defendant is not located in the United States notwithstanding, amended Rule 4 may not escape adverse foreign reaction. ${ }^{119}$. The rulemakers' assertions about the nature of the waiver of service mechanism and their expressed hopes are in the note; with the admittedly significant exception of cost-shifting, the rule remains essentially the same. ${ }^{120}$ One may still question whether a private litigant has the power to waive her country's sovereignty objections, ${ }^{121}$ and whether more than an assertion (or a label) distinguishes a waiver mechanism that requires transmission abroad of a copy of the complaint and an official form from formal service of process. ${ }^{122}$

Thus, the changes that have been made may not satisfy foreign governments that prohibit service by mail from abroad, including those that have made a reservation under Article 10(a) of the Service Convention. ${ }^{123}$ After all, it is

118. See Judicial Conference Proposals, supra note 115, at 8-9; Amendments to Federal Rules of Civil Procedure, 113 S. Ct. 475 (1993) [hereinafter 1993 Amendments]. For a description of the legislative process by which these amendments became effective, see William J. Hughes, Congressional Reaction to the 1993 Amendments to the Federal Rules of Civil Procedure, 18 SETON HALL LEG. J. 1 (1993).

119. See Statement of Gary B. Born before the Advisory Committee on Civil Rules, Chicago, Illinois, Feb. 2, 1990, at 24-26 [hereinafter Born Statement] (copy on file with author); letter from Hon. Edmund Hosker, First Secretary (Commercial) of the British Embassy, to Joseph F. Spaniol, Jr., Secretary, Committee on Rules of Practice and Procedure (Apr. 9, 1992) [hereinafter 1992 British Letter] (copy on file with author).

120. Unfortunately, in revising the note to reflect the deletion of cost-shifting when either the plaintiff or the defendant is not located in the United States, the rulemakers failed to clean up the introductory paragraph to subdivision (d):

Subdivision (d). This text is new, but is substantially derived from the former subdivisions (c) (2) (C) and (D), added to the rule by Congress in 1983. The aims of the provision are to eliminate the costs of service of a summons on many parties and to foster cooperation among adversaries and counsel. The rule operates to impose upon the defendant those costs that could have been avoided if the defendant had cooperated reasonably in the manner prescribed. This device is useful in dealing with defendants who are furtive, who reside in places not easily reached by process servers, or who are outside the United States and can be served only at substantial and unnecessary expense. Illustratively, there is no useful purpose achieved by requiring a plaintiff to comply with all the formalities of service in a foreign country, including costs of translation, when suing a defendant manufacturer, fluent in English, whose products are widely distributed in the United States. See Bankston v. Toyota Motor Corp., 889 F. 2d 172 (8th Cir. 1989).

1993 Amendments, supra note 118, 113 S. Ct. at 634-35 (emphasis added). See 1992 British Letter, supra note 119 , at 1-2.

121. See Burbank, supra note 72, at 1485; letter from Hon. Edwin D. Williamson, Legal Adviser, Department of State, to Joseph F. Spaniol, Jr., Secretary, Committee on Rules of Practice and Procedure (June 12, 1992) [hereinafter State Department Letter] (copy on file with author).

122. See letter from Professor George Rutherglen to Hon. Joseph R. Weis, Jr., Chairman, Committee on Rules of Practice and Procedure, 3 (Aug. 24, 1990) ("Only an attorney could distinguish between receipt of the request for waiver, which has already occurred, and formal service, which is to be waived.") (copy on file with author).

123. "Provided the State of destination does not object, the present Convention shall not interfere with (a) the freedom to send judicial documents, by postal channels, directly to persons abroad." Hague Service Convention, supra note 2, art. 10(a), 20 U.S.T. at 363, 658 U.N.T.S. at 169. "[W]hether a failure to make a reservation with respect to article $10(\mathrm{a})$ of the Convention constitutes consent to service by mail is a matter on which U.S. courts are divided." Burbank, supra note 72, at 1486-87 (footnotes omitted). 
our State Department's view that, with or without cost-shifting, "[a] United States provision authorizing 'waiver of service' .. . does not conform to formal service of process which was intended by the Hague Service Convention." 124 The rulemakers' notion that plaintiffs will prefer formal service under the Convention to waiver of service "in a foreign country like the United Kingdom"125 is wishful thinking. In any event, like the 1963 amendment to Rule $4,{ }^{126}$ the waiver option presupposes a high degree of sophistication on the part of plaintiffs' lawyers and leaves the choice to them. ${ }^{127}$ Given the history and content of critical comments, it might have been prudent to exempt international civil litigation from the waiver mechanism until such time as the rulemakers could study the results of the survey of foreign governments that the State Department agreed to conduct after the September 1992 meeting. ${ }^{128}$

The rulemakers' persistence in this matter is unfortunate for reasons other than the likelihood that it will provoke additional controversy. Insistence on the availability of the waiver mechanism for use in foreign countries where it is not permitted is inconsistent with three of the major advances made in the 1993 amendments to Rule 4. One of those advances, bespeaking concern for international cooperation and a willingness to subordinate unilateral assertions of power, reposes in amended Rule 4(f), under which "[s]ervice by methods that would violate foreign law is not generally authorized." 129 Another consists in the greater clarity, coherence, and guidance provided by amended Rule 4(f), which replaces a hodge-podge of alternatives seemingly available for service abroad ${ }^{130}$ - some of them that were not perhaps available ${ }^{131}$ and others dangerous to use ${ }^{132}$-with an exclusive list of options that should reduce the dangers for unsophisticated litigants and attorneys. The third and related advance lies in drawing attention to the Service Convention and other similar treaties that may apply. ${ }^{133}$

The rulemakers' persistence is also unfortunate because, in addition to rejecting foreign protests against the extension of the proposed waiver of service mechanism abroad, they rejected the positions of the Departments of Justice and State, which also opposed the extension. ${ }^{134}$ Some members of the

124. Executive Branch Comments, supra note 106, at 3. See Born Statement, supra note 119, at 25 n.33; letter from Michael Hoenig, Esq., to Hon. Joseph F. Weis, Jr., Chairman, Committee on Rules of Practice and Procedure, 3-5 (March 15, 1990) (copy on file with author).

125. 1993 Amendments, supra note $118,113 \mathrm{~S}$. Ct. at 637 (Rule 4(d) advisory committee note).

126. See supra text accompanying note 88 .

127. See Executive Branch Comments, supra note 106, at 3 ("The 'waiver of service' provision will mislead litigants into believing that proper service has been made for the purpose of enforcing resulting United States judgments in foreign jurisdictions.").

128. See Peter H. Pfund, Remarks, 57 LAw \& Contemp. Probs. 159, 160 (Summer 1994).

129. 1993 Amendments, supra note $118,113 \mathrm{~S}$. Ct. at 642 (Rule 4(f) advisory committee note).

130. See supra text accompanying note 88 .

131. See, e.g., Umbenhauer v. Woog, 969 F.2d 25, 30 n.5 (3d Cir. 1992) ("[W]e need not decide whether process may ever properly be served on a foreign defendant under Rule 4(c)(2)(C)(ii).").

132. See supra text accompanying notes $86-87$.

133. But see infra text accompanying notes $148-59$ (criticizing interpretations of Service Convention in Advisory Committee Note to amended Rule 4(f)(3)).

134. See Executive Branch Comments, supra note 106. 
Advisory Committee apparently discounted executive branch objections because they emerged only after foreign governments protested. ${ }^{135}$ The fear was also expressed that to yield to the protests would be to politicize the rulemaking process. ${ }^{136}$ Moreover, the Advisory Committee may have taken comfort in the notion that Congress could change the proposal if it deemed the objections serious. ${ }^{137}$ The Standing Committee's change of position on cost-shifting is to be applauded, but although not too late, it may be too little. ${ }^{138}$

What, then, has motivated the rulemakers to cling to a provision the premises and assumptions of which have been repeatedly questioned and which has been, and may still be, controversial both in foreign countries, including some of our treaty partners, and in that branch of the federal government primarily charged with the conduct of foreign relations? First, there was impatience with the unjustified imposition of cost and delay, problems that may be especially serious in international civil litigation. ${ }^{139}$ Second, there was a normative view that litigants from foreign countries should be treated the same as domestic litigants unless there are very good reasons to treat them differently, ${ }^{140}$ a view that can color interpretations of international agreements. ${ }^{141}$ Third, the rulemakers apparently do not regard either foreign law, customary international law, or the Hague Convention as providing such reasons where the question is waiver of service. Finally, some members of the Advisory Committee do not take seriously executive branch objections that they deem merely reactive, and they may discount such objections when the executive branch fails to speak with one voice or appears to change position. ${ }^{142}$

b. Court-directed service. The other controversial provision in the 1993 amendments to Rule 4 that addresses problems in international civil litigation permits service upon individuals in a foreign country "by other means not

135. See Advisory Committee on the Civil Rules, Minutes of Meeting, Apr. 13-15, 1992, at 5 [hereinafter April 1992 Minutes] (copy on file with author).

136. See id.

137. See id. at 4-5.

138. See supra text accompanying notes 120-29.

139. See supra note 120.

140. See April 1992 Minutes, supra note 135, at 5 (Advisory Committee member "concluded that the Justice-State-British Embassy position is basically unfair").

141. See id. at 4 ("It seems unlikely that Congress intended to give a benefit to foreign defendants that it would not give to domestic defendants."). In context, this appears to be a reference to the supposed intent of the Senate in consenting to the Service Convention. See also id. at 9-10; infra text accompanying notes 191-95.

142. See April 1992 Minutes, supra note 135, at 5; see also id. at 9 (Rule 26). In an attachment to the letter from the Chair of Advisory Committee on Civil Rules to the Chair of the Standing Committee that identified and discussed criticisms and explained changes made by the Advisory Committee, the matter was put as follows concerning Rule 4:

The Department of Justice, which had expressed no comment when the rule was originally proposed, has subsequently taken the position, essentially echoing concerns of the Department of State, that, to avoid possible offense to other governments, it would be preferable for the rule to restrict the request-for-waiver procedure to defendants located within this country. Standing Committee Proposals, supra note 104, Appendix E, Attachment B, at 1. 
prohibited by international agreement as may be directed by the court."143 This is a stop-gap measure designed to deal with unusual cases, including cases in which the court determines that service will require a violation of foreign law. ${ }^{144}$ Although not objectionable on its face, its drafting history reveals, and the Advisory Committee Note confirms, that it reflects flawed premises, including erroneous interpretations of the Service Convention. That same history reveals successive decisions to remit controversial interpretations to the Note.

In an earlier version the amended rule would have permitted a court to direct service "by means not authorized by international agreement or not consistent with the law of a foreign country, if the court finds that internationally agreed means or the law of a foreign country (A) will not provide a lawful means by which service can be effected, or (B) in cases of urgency, will not permit service within the time required by the circumstances."145 I criticized that formulation both for lack of candor and for conflict with the Service Convention. ${ }^{146}$ The rulemakers have sought to make clear that the latest version does not permit violation of an international agreement, ${ }^{147}$ but they have also adhered to the view that the Hague Convention authorizes alternate methods of service in circumstances where, fairly interpreted, it does not do so.

According to the Advisory Committee, the "Hague Convention does not specify a time within which a foreign country's Central Authority must effect service, but Article 15 does provide that alternate methods may be used if a Central Authority does not respond within six months." ${ }^{148}$ Taking that position, the rulemakers cite as one possible occasion for use of alternate methods of service under amended Rule 4(f)(3) "the failure of the foreign country's Central Authority to effect service within the six-month period provided by the Convention." 149

143. 1993 Amendments, supra note $118,113 \mathrm{~S}$. Ct. at 485 (Rule 4 (f)(3)). Still another controversial provision is not explicitly directed at international civil litigation but would have its major impact there. Rule $4(k)(2)$ provides:

If the exercise of jurisdiction is consistent with the Constitution and laws of the United States, serving a summons or filing a waiver of service is also effective, with respect to claims arising under federal law, to establish personal jurisdiction over the person of any defendant who is not subject to the jurisdiction of the courts of general jurisdiction of any state.

Id. at 490. For discussion, see Burbank, supra note 72 , at 1484 n.164. See infra note 347; text accompanying notes $349-51$.

144. 1993 Amendments, supra note 118, $113 \mathrm{~S}$. Ct. at 643 (Rule 4(f) advisory committee note).

145. Proposed Amendments to the Federal Rules of Civil Procedure 12-13 (1990), quoted in Burbank, supra note 72 , at 1489 . For the full text of the proposed rule and note, see HouSE DoC., supra note 101 , at $61-102$.

146. See Burbank, supra note 72 , at $1489-90$.

147. See April 1992 Minutes, supra note 135, at 5 . There may, however, still be room for argument whether a method not authorized is prohibited. Cf. Advisory Committee on the Civil Rules, Minutes of Civil Rules Committee Meeting, New York City, June 6-8, 1990 at 10 (Rule 26) [hereinafter June 1990 Minutes] (copy on file with author). But see infra text accompanying note 156 (Hague Service Convention is exclusive and therefore prohibits what it does not authorize).

148. 1993 Amendments, supra note $118,113 \mathrm{~S}$. Ct. at 642 (Rule $4(\mathrm{f})$ advisory committee note).

149. Id. at 643 . 
Article 15 does not "provide that alternate methods may be used if a Central Authority does not respond within six months." The article's only textual reference to "six months" appears in paragraphs enabling contracting states to make a formal declaration that would permit the entry of default judgments in the absence of proof of service under certain conditions. ${ }^{150}$ The first of those conditions is that "the document was transmitted by one of the methods provided for in this Convention." 151 The second is that "a period of time of not less than six months, considered adequate by the judge in the particular case, has elapsed since the date of the transmission of the document."152 Nothing in the negotiating history contradicts the language of Article 15 or supports the Advisory Committee's interpretation, ${ }^{153}$ nor do descriptions of the Convention during the ratification process. ${ }^{154}$ The way to deal with difficulties in effecting service under the Hague Convention is through diplomatic channels, ${ }^{155}$ not through unilateral resort to means that it does not

150. Article 15 provides:

Where a writ of summons or an equivalent document had to be transmitted abroad for the purpose of service, under the provisions of the present Convention, and the defendant has not appeared, judgment shall not be given until it is established that-

(a) the document was served by a method prescribed by the internal law of the State addressed for the service of documents in domestic actions upon persons who are within its territory, or

(b) the document was actually delivered to the defendant or to his residence by another method provided for by this Convention,

and that in either of these cases the service or the delivery was effected in sufficient time to enable the defendant to defend.

Each Contracting State shall be free to declare that the judge, notwithstanding the provisions of the first paragraph of this article, may give judgment even if no certificate of service or delivery has been received, if all the following conditions are fulfilled-

(a) the document was transmitted by one of the methods provided for in this Convention,

(b) a period of time of not less than six months, considered adequate by the judge in the particular case, has elapsed since the date of the transmission of the document,

(c) no certificate of any kind has been received, even though every reasonable effort has been made to obtain it through the competent authorities of the State addressed.

Notwithstanding the provisions of the preceding paragraphs the judge may order, in case of urgency, any provisional or protective measures.

Hague Service Convention, supra note 2, art. 15, 20 U.S.T. at 364, 658 U.N.T.S. at 171-73.

151. Id.

152. Id.

153. See, e.g., Conférence de La Haye de Droit International Privé, III ACTES ET DoCUMENTS DE LA DIXIEME SESSION, 92-98, 114-15, 125-26, 129, 133, 251-63, 267-70, 314, 321, 337-39, 376-78 (1965) [hereinafter ACTES ET DOCUMENTS].

154. See S. EXEC. Doc. C, 90th Cong., 1st Sess. 6 (1967) [hereinafter 1967 SENATE DocumENT] (letter of submittal); id. at 21 (report of U.S. delegation); S. EXEC. REP. No. 6, 90th Cong., 1st Sess. 2 (1967) [hereinafter 1967 SENATE REPORT]; id. at 14-15 (statement of Philip W. Amram). The Chief of the U.S. delegation subsequently described this part of Article 15 as follows: "However, a Contracting State may reserve the right to allow the Court entry of judgment in the absence of proof of service, if six months have elapsed since the date of transmission and all reasonable efforts have been made to obtain proof of service." Richard D. Kearney, The United States and International Cooperation to Unify Private Law, 5 CORNELl INT'L L.J. 1, 5 (1972).

155. This view was expressed by the Executive Branch in its comments: 
authorize and, hence, as the exclusive source of rules among signatory states, prohibits. ${ }^{156}$

Similarly, the Advisory Committee Note to amended Rule 4(f)(3) asserts that "[t]he Hague Convention . . . authorizes special forms of service in cases of urgency if convention methods will not permit service within the time required by the circumstances." ${ }^{157}$ The rulemakers apparently relied on another provision in Article 15, that "[n]otwithstanding the provisions of the preceding paragraphs the judge may order, in case of urgency, any provisional or protective measures." ${ }^{158}$ On its face, this language means simply that, even though Article 15 constrains the entry of a default judgment, it does not prohibit "provisional or protective measures" such as injunctions or attachments of property "in case of urgency." Nothing in that language provides a general authorization for alternate methods of service in such cases, and neither does anything in the negotiating history. ${ }^{159}$

The Advisory Committee was made aware of the dubiety of these interpretations during the comment period. Unfortunately, one commentator who was attentive to some of the problems ${ }^{160}$ was more interested in ensuring that alternate methods would be available for other situations, ${ }^{161}$ and he was sanguine about occasional violations of the Hague Convention pursuant to a Federal Rule of Civil Procedure. ${ }^{162}$ Other commentators simply asserted that

Article 14 of the Service Convention states that any difficulties in connection with the transmission of judicial documents for service shall be settled through diplomatic channels. In fact, some of the problems outlined in the Advisory Committee Notes, such as refusal of certain foreign central authorities to serve complaints with punitive damage counts, have been satisfactorily resolved as a result of meetings of representatives of states party to the Service Convention under the auspices of the Hague Conference on Private International Law.

Executive Branch Comments, supra note 106, at 4; see also Born Statement, supra note 119, at 19 n.25; United Kingdom Embassy Note, supra note 100.

156. See Volkswagenwerk Aktiengesellschaft v. Schlunk, 486 U.S. 694 (1988); Executive Branch Comments, supra note 106, at 2; infra note 162 .

157. 1993 Amendments, supra note 118,113 S. Ct. at 643.

158. Supra note 150.

159. See ACTES ET DOCUMENTS, supra note 153 , at $98,115,129,270,321,337-39,378$. The provision was not the subject of comment or discussion in the documents submitted to the Senate when its consent was sought. See 1967 SENATE DOCUMENT, supra note 154; 1967 SENATE REPORT, supra note 154. Note, however, R. H. Graveson, The Tenth Session of the Hague Conference of Private International Law, 14 INT'L \& COMP. L.Q. 528, 540 (1965) ("Furthermore, the reservation is made for jurisdiction in case of urgency to take provisional or protective measures") (emphasis added). See Burbank, supra note 72 , at $1489-90$ n.200.

160. This commentator noted that,

[a]lthough Article 15 refers to a six month period for service under the Convention, I suspect that this period was probably intended to be confined to cases involving default judgments against defendants who evade service. If so, the new Rule $4(f)$ would permit service in violation of the Convention and thus would be likely to produce unenforceable U.S. judgments and might also prompt retaliatory measures by foreign states.

Born Statement, supra note 119, at 19.

161. See id. at $20-21$. Subsequently, "[t]he addendum for emergencies suggested by Mr. Born was approved as a fit to the Hague Convention, although [two members] questioned the need for such a provision." June 1990 Minutes, supra note 147, at 9.

162. See Born Statement, supra note 119, at 19-20 \& n.26, 20-21 \& n.28, 23. So for a time were members of the Advisory Committee. When concern was expressed that "the rules propose to authorize service in violation of a treaty ... it was pointed out that some signatories do not obey the 
the Service Convention authorizes resort to alternate methods if a foreign government is dilatory. ${ }^{163}$ Moreover, during the initial comment process, both the Securities and Exchange Commission (the "SEC") 164 and the Department of Justice ${ }^{165}$ pressed for greater flexibility in the use of alternate methods of service. When the State Department's views finally were expressed, at first indirectly ${ }^{166}$ and then directly, ${ }^{167}$ they were insufficiently specific to prompt deletion from the note of controversial interpretations that had been eliminated from the text of the rule. ${ }^{168}$

The progressive sanitizing of Rule 4(f)(3), by eliminating what might have been construed as permission to violate a treaty and remitting controversial interpretations of the Service Convention to the note, was a course consistent with that advocated by members of the Advisory Committee in connection with the proposal to amend Rule 26:

And another factor that some members of the Committee were concerned about is frankly beyond the ken of this Committee, but important, I suppose, and that is honoring diplomatic efforts that are undertaken and accomplished by other branches of government and not offending the processes that are set up, for example. And, frankly, there's a fundamental tension between those kinds of concerns.

And in one respect, one of the people on the Committee-your proposal is consistent with the view that some members of the Committee had, that we should express-and that may be the adverb word-express deference to processes that have been established through other channels and by other branches of government. After expressing that deference-I don't mean as a complete ritual, but after expressing that deference, then proceed with what we need to do to do justice. ${ }^{169}$

c. Rule 26. Although the rulemakers chose to go forward with, while making changes in, the controversial provisions in Rule 4, the Standing Committee eliminated a proposed amendment to Rule 26 regarding discovery abroad ${ }^{170}$

treaty, and the present rule permits such deviance." June 1990 Minutes, supra note 147, at 9.

163. See, e.g., letter from Edwin R. Alley, Esq., to Hon. James Macklin, Jr., Secretary, Committee on Rules of Practice and Procedure, 2 (Mar. 14, 1990) (copy on file with author).

164. See Statement of Thomas L. Riesenberg, Assistant General Counsel, U.S. Securities and Exchange Commission, Washington, D.C., Before the Committee on Rules of Practice and Procedure of the Judicial Conference of the United States, Chicago, Illinois, Feb. 2, 1990, at 6-16 [hereinafter SEC Statement] (copy on file with author).

165. See United States Department of Justice, Supplemental Comments on Proposed Amendments to the Federal Rules of Civil Procedure 1-2 (Mar. 15, 1990) [hereinafter DOJ 1990 Comments] (copy on file with author).

166. See Executive Branch Comments, supra note 106, at 3-4.

167. See State Department Letter, supra note 121.

168. The Standing Committee eliminated from the text of Proposed Rule 4(f)(3) the conditional language, "if the court finds that internationally agreed means or the law of the foreign country (A) will not provide a lawful means by which service can be effected or (B), in cases of urgency, will not permit service of process within the time required by the circumstances." Compare Proposed Amendments to the Federal Rules of Civil Procedure and the Federal Rules of Evidence 8 (May 1992) (copy on file with author) with Standing Committee Proposals, supra note 104, at 12. It was deleted because it "may have contributed to controversy and was not needed." Id. Appendix $\mathrm{H}$, at 4 (emphasis added). It was not needed because the note remained essentially the same.

169. Hearings on the Proposed Amendments to the Federal Rules of Appellate Procedure and the Federal Rules of Civil Procedure, San Francisco, California, Jan. 9, 1990, at 86-87 [hereinafter January 1990 Hearing] (copy on file with author).

170. See supra text accompanying note 102 . 
that had also been the subject of adverse comment by foreign governments as well as by the Departments of Justice and State. ${ }^{171}$ Originally viewed as a vehicle to codify the position of a minority of the Supreme Court in the Aérospatiale case ${ }^{172}$ by requiring first resort to an applicable convention except in certain conditions, the proposed amendment had a tortured history thereafter. ${ }^{173}$ In response to negative comments, including those by the SEC $^{174}$ and the Justice Department, ${ }^{175}$ the Advisory Committee appeared to change direction, but the Advisory Committee Note was confusing. Ultimately, in the face of continuing controversy, ${ }^{176}$ the Standing Committee apparently decided that the game was not worth the candle.

Members of the Standing Committee may have felt that, particularly in light of the Supreme Court's actions in returning some of the earlier proposals and requesting a report, ${ }^{177}$ something had to go. The differing perspectives of the Justice and State Departments at the end of the process ${ }^{178}$ mirrored confusion about the Rule 26 proposal throughout the process. The proposed amendment to Rule 26 was an attempt to discipline discovery abroad with attention to international relations. Appearing at first far-reaching, it was watered down to the point of insignificance. Indeed, the result of the Advisory Committee's volte face was regarded in some quarters as positively harmful to international relations. ${ }^{179}$ In those circumstances, the better part of valor was to preserve the status quo.

171. See supra text accompanying note 100; Executive Branch Comments, supra note 106, at 5-8; State Department Letter, supra note 121. For another account of the proposed amendment to Rule 26, see Gary B. Born, The Hague Evidence Convention Revisited: Reflections on its Role in U.S. Civil Procedure, 57 LAw \& ConTEMP. PROBS. 77 (Summer 1994).

172. Société Nationale Industrielle Aérospatiale v. United States Dist. Court for the So. Dist. of Iowa, 482 U.S. 522 (1987).

173. See Burbank, supra note 72 , at 1494-95.

174. See SEC Statement, supra note 164 , at 16-19.

175. See DOJ 1990 Comments, supra note 165 , at $2-4$.

176. See Executive Branch Comments, supra note 106, at 5-8; State Department Letter, supra note 121.

177. The Advisory Committee was informed in February 1992 "that the Court would in the future like a memorandum explaining the contentious issues resolved." Advisory Committee on the Civil Rules, Minutes of Meeting of February 21, 1992, at 1 (copy on file with author): Appendix $H$ to the Judicial Conference Rules materials for September, 1992 is a document entitled "Proposed Rules Amendments Generating Substantial Controversy."

178. See Executive Branch Comments, supra note 106, at 5-7; April 1992 Minutes, supra note 135, at 9 .

179. See letter from Hon. Adair Dyer, First Secretary of the Permanent Bureau of the Hague Conference on Private International Law, to Edward R. Alley, Esq. (Aug. 29, 1990), enclosed with letter from Edward R. Alley, Esq., to Hon. Joseph F. Weis, Jr., Chairman, Committee on Rules of Practice and Procedure (Sept. 5, 1990) (copies on file with author); State Department Letter, supra note 121 (expressing "great concern" about "discovery in contravention of foreign law or applicable international convention" and arguing that proposed Rule 26(a)(5) "establishes a standard which encourages U.S. parties to demonstrate that discovery methods authorized by a treaty are 'inadequate or inequitable' and thus need not be followed in a given case."); Born, supra note 171, at 92-96. 


\section{Federal Judge-Made Law}

Professor Hazard has reminded us that the Federal Rules of Civil Procedure are not the only source of procedural rules applied by the federal courts. ${ }^{180}$ The observation is as true for federal civil litigation having international aspects as it is for litigation that is wholly domestic. Apart from procedural law in statutes, local rules of court, standing orders, and treaties, federal judges have limited power to create procedural law in their decisions. ${ }^{181}$ Moreover, both in interpreting existing law that is not created in cases and in filling gaps in it, federal judges can exercise power that differs only in degree from their power to fashion common law. ${ }^{182}$

Some of the rules that federal judges have fashioned or that are the product of interpretation are among the most consequential in international civil litigation, and some of them are associated, rightly or wrongly, with the field of procedure. Thus, federal judge-made law "interpreting" the Due Process Clause of the Fourteenth Amendment often determines whether a foreign defendant can be subjected to the jurisdiction of a state (or federal) court. ${ }^{183}$ Moreover, federal judge-made law will often determine whether international civil litigation remains in federal court despite an objection of forum non conveniens ${ }^{184}$ or a motion to dismiss grounded in a contractual forum selection clause specifying a foreign forum. ${ }^{185}$ And again, federal courts may be called upon to interpret and apply a variety of statutes and rules that regulate, in varying levels of detail, the incidents of international civil litigation. On occasion, that process requires mediation between apparently conflicting norms. ${ }^{186}$

In previous work, I have examined claims that there is, or should be, a discrete field of international civil litigation and that special rules apply in such litigation to problems they share with domestic litigation. Disagreeing with such claims, I have argued that

[i]t seems more accurate to view international civil litigation as part of a process of cross-fertilization in which (1) doctrine and techniques developed in the context of domestic cases are brought to bear on problems presented in international litigation, and (2) the increasingly international dimensions of litigation in our courts prompt changes in doctrine and techniques, which are then applied in domestic cases. ${ }^{187}$

180. See Geoffrey C. Hazard, Jr., Discovery Vices and Trans-Substantive Virtues in the Federal Rules of Civil Procedure, 137 U. PA. L. REV. 2237, 2244-46 (1989).

181. See, e.g., Thomas W. Merrill, The Common Law Powers of Federal Courts, 52 U. CHI. L. REV. 1,24 (1985).

182. See Peter Westen \& Jeffrey S. Lehman, Is There Life for Erie after the Death of Diversity?, 78 MICH. L. REV. 311, 332-36 (1980).

183. See, e.g., Omni Capital Int'l v. Rudolf Wolff \& Co., 484 U.S. 97 (1987); Asahi Metal Indus. Co. v. Superior Court, 480 U.S. 102 (1987).

184. See, e.g., Piper Aircraft Co. v. Reyno, 454 U.S. 235 (1981).

185. See, e.g., M/S Bremen v. Zapata Off-Shore Co., 407 U.S. 1 (1972).

186. See, e.g., Societe Internationale Pour Participations Industrielles et Commerciales, S.A. v. Rogers, 357 U.S. 197 (1958).

187. Burbank, supra note 72 , at 1459 . Of course, "[i]nternational cases in our courts may present occasions for the application of rules of law that are not pertinent in wholly domestic cases. Act of state and foreign sovereign immunity . . . are two prominent examples." Id. at 1472-73 (footnote 
As I have also pointed out, it would be surprising to find many special rules of procedure for international civil litigation in federal courts. A major normative premise of the Federal Rules of Civil Procedure has been not only that the same rules should apply in all federal courts but that they should apply in all cases in those courts. The same quest for uniformity undergirds federal judge-made procedural law. Substantial controversy now attends the premise of trans-substantive rules, but its hold is strong. ${ }^{188}$ Moreover, there are additional reasons why federal lawmakers may not wish to have special rules of procedure for international civil litigation.

Some of the 1993 amendments to Rule 4 of the Federal Rules of Civil Procedure represent a further departure from the norm of trans-substantive procedure-as for instance by substituting an exclusive menu of methods of service abroad in place of a list of optional alternatives. ${ }^{189}$ Those proposals cling to the norm, however, in connection with the proposed waiver of service mechanism, and only extraordinary action by the Standing Committee broke the mold for cost-shifting. ${ }^{190}$ One reason, I have suggested, for persistence with regard to the waiver mechanism has been the view that foreign litigants should not be treated differently than domestic litigants in the absence of compelling reasons. ${ }^{191}$ Different treatment could prompt concern about invidious discrimination against foreign litigants. ${ }^{192}$ That, however, is apparently not what has most concerned the rulemakers. Both in connection with the waiver of service mechanism ${ }^{193}$ and in their deliberations on Rule $26,{ }^{194}$ members of the Advisory Committee expressed fear that differences in the rules would confer an unfair advantage on foreign litigants. Moreover, to the extent that their efforts have intersected with existing law, whether found in legislation or treaties, they have been reluctant to conclude that other U.S. lawmakers would have conferred such advantages. ${ }^{195}$ In this, they are echoing attitudes evident in the decisions of the Supreme Court interpreting the Service and Evidence Conventions. Neither the decisions nor the attitudes suggest a bright future for a federal common law of international civil litigation.

I: have argued elsewhere that in both Volkswagenwerk Aktiengesellschaft $v$. Schlunk, ${ }^{196}$ interpreting the Service Convention, and Société Nationale Industrielle Aérospatiale v. United States District Court for the Southern District of Iowa, ${ }^{197}$ interpreting the Evidence Convention, the Court failed to accord

omitted).

188. See id. at 1466-67.

189. See supra text accompanying note 130.

190. See supra text accompanying notes 106-42.

191. See supra text accompanying note 140 .

192. See Hearings on the Proposed Amendments to the Federal Rules of Appellate Procedure and the Federal Rules of Civil Procedure, Chicago, Illinois, Feb. 2, 1990, at 46 (copy on file with author).

193. See supra text accompanying note 140 .

194. See April 1992 Minutes, supra note 135, at 9-10; January 1990 Hearing, supra note 169 , at $84-85$.

195. See supra note 141 and accompanying text.

196. 486 U.S. 694 (1988).

197. 482 U.S. 522 (1987). 
those treaties "the respect due an ordinary federal statute." 198 In Aérospatiale, however, the Court did treat the Evidence Convention like an ordinary federal statute by refusing seriously to engage the Convention's policies out of concern for the integrity of the Federal Rules of Civil Procedure. ${ }^{199}$ One attitude that emerges from the opinions is a determination to preserve as much domestic procedural law as possible, particularly if it reposes in the Federal Rules. Another, related attitude is reluctance to interpret treaties so as to confer greater rights on foreign litigants than their domestic opponents. The latter impulse was so strong in Aerrospatiale that it prompted not only speculation about what our treatymakers would or would not have done ${ }^{200}$ but also dubious interpretations of things that they in fact had done. ${ }^{201}$

The Supreme Court has, of course, counseled special concern for the interests of foreign litigants and the need for smooth international relations, ${ }^{202}$ and it did so in Aérospatiale. ${ }^{203}$ In addition, the Court has on occasion expressed an attitude quite the opposite of the preference for domestic law that is evident in the majority opinions in Schlunk and Aérospatiale, as well as in the recent work of the rulemakers. ${ }^{204}$ Foreign litigants have not, however, reaped many benefits, because rules originally formulated for their benefit have been extended to domestic litigation, ${ }^{205}$ or because such rules are not worthy of the name. ${ }^{206}$ Moreover, it is possible that "the Court's schizophrenic approach to treaties is simply a function of calculations about when it is in the judiciary's interest to share power."207

\section{Treatymaking}

It may seem odd to put treaties last among the methods of lawmaking for international civil litigation, at least in an article celebrating the one hundredth anniversary of the Hague Conference on Private International Law. My reasons for doing so derive from a conviction that the historical and institutional contexts in which our limited experience has occurred are essential to

198. Burbank, supra note 72 , at 1493.

199. See id. at 1493-94; Patricia Anne Kuhn, Comment, Société Nationale Industrielle Aérospatiale: The Supreme Court's Misguided Approach to the Hague Evidence Convention, 69 B.U. L. REV. 1011, 1048 (1989).

200. See Société Nationale Industrielle Aérospatiale v. United States Dist. Ct. for the So. Dist. of Iowa, 482 U.S. 522, 536-37 (common law countries would not have agreed to Article 23 if Convention were exclusive means of obtaining evidence abroad). But see id. at 563-64 (Blackmun, J., concurring in part and dissenting in part) (pointing out the limited scope of Article 23 reservations).

201. See id. at 537-38 (Article 27 permits contracting states to use more liberal methods). As correctly observed by Justice Blackmun, however, "[t]he only logical interpretation of . . Article [27] is that a state receiving a discovery request may permit less restrictive procedures than those designated in the Convention." Id. at $551 \mathrm{n} .2$ (Blackmun, J., concurring in part and dissenting in part).

202. See, e.g., Asahi Metal Indus. Co. v. Superior Court, 480 U.S. 102, 116 (1987).

203. See Aérospatiale, 482 U.S. at 546.

204. See, e.g., Mitsubishi Motors Corp. v. Soler Chrysler-Plymouth, Inc., 473 U.S. 614, 639-40 n.21

(1985); M/S Bremen v. Zapata Off-Shore Co., 407 U.S. 1, 9 (1972); Kuhn, supra note 199, at 1048-49.

205. See Burbank, supra note 72 , at 1466-67.

206. See Aérospatiale, 482 U.S. at 554-56 (Blackmun, J., concurring in part and dissenting in part).

207. Burbank, supra note 72, at 1497. 
understanding and evaluating that experience. In addition, the success of a treaty, particularly in the area of private international law, may depend to a great extent on the processes of domestic lawmaking in which it is given effect.

When the United States joined the Hague Conference in 1964, it took essentially its first steps towards seeking general international agreements in the field of private international law, including procedural law for cases with international aspects. The United States's previous experience was largely with unilateral lawmaking. Moreover, unilateralism is not only an apt description of our procedural lawmaking history prior to 1964 . It was also the preferred normative stance of many Americans, whether out of the general belief that foreign entanglements should be avoided or a more focused concern that, in matters of private international law, the federal government lacked the power to, or at least should not, preempt state lawmaking institutions. ${ }^{208}$

The adoption of the Federal Rules of Civil Procedure marked an important turning point in attitudes towards the proper relationship between federal and state law in the area of procedure and also ultimately had an impact on the movement to seek international cooperation. ${ }^{209}$ At the same time, the Federal Rules have made such cooperation more difficult, in part because the rulemakers and the federal courts cling to the rhetoric, if not the reality, of uniform and trans-substantive procedure, ${ }^{210}$ and in part because the first consequential treatment of international civil litigation in the Federal Rules occurred just before we joined the Hague Conference.

The 1963 amendments to the Federal Rules ${ }^{211}$ and the 1964 amendments to the Judicial Code $^{212}$ were double-edged. The legislative amendments in particular were very generous to foreign litigants and tribunals in need of judicial assistance in this country. The rules amendments provided a counterweight, furnishing great flexibility but also asserting power with no requirement of deference to the laws or policies of foreign countries. The hope was expressed that other countries would follow our enlightened example, ${ }^{213}$ and

\footnotetext{
208. See supra text accompanying notes 1-9.

We maintained an isolationist position in the field of private international law long after we had abandoned this ostrich posture in the public law area. For example, as late as 1958 the United States delegation to the United Nations Conference on International Commercial Arbitration, because of the traditional concern regarding federal-state relations, was under instructions not to participate actively in formulating a convention for the recognition of foreign arbitral awards. After the conference adopted such a convention, the delegation recommended against our adherence thereto on the ground, among others, that the United States lacked a sufficient domestic legal basis for acceptance of an advanced international convention on the subject of arbitration. This always struck me as making us out even more backward than we were.
}

Kearney, supra note 154, at 2 (footnote omitted). For a description of consular agreements, diplomatic notes, and treaties dealing with specialized aspects of judicial assistance, see First Annual Report, supra note 44 , at $8-9$.

209. See supra text accompanying notes 8-9; Jones, supra note 6, at 561-62.

210. See supra text accompanying notes 189-207. For the gap between the rhetoric and the reality, see Burbank, supra note 76, at 1929-41.

211. See supra text accompanying notes 78-98.

212. See supra text accompanying notes $35-73$.

213. See supra text accompanying note 66 . 
a prominent rulemaker, although regretting this country's lack of initiative in the international arena, saw no necessary adverse effect of the 1963 amendments on international cooperation. ${ }^{214}$ It is time to assess the history of our attempts to cooperate.

1. The Hague Service Convention. The members of the first official U.S. delegation to the Hague Conference ${ }^{215}$ returned with what they hoped would be the first multilateral convention on private international law to which the United States was a party, the Service Convention. In describing that treaty to the Senate, they stressed how little the United States, and how much other countries, would have to give up. ${ }^{216}$ They also praised Congress's farsightedness in unilaterally liberalizing our arrangements for judicial assistance, ${ }^{217}$ claiming that the recently enacted legislation had a dramatic impact on the drafting process and, hence, on the final treaty. ${ }^{218}$

It is hard to take seriously an imputation of farsightedness to Congress in connection with the 1964 amendments to the Judicial Code. ${ }^{219}$ Moreover, assertions that our unilateral act of generosity had been influential in shaping the Service Convention appear to have been designed to persuade senators that international procedure was an area in which we could exercise leadership without surrendering anything of importance. In any event, we did not lead the effort that resulted in the Service Convention; we followed and almost missed the boat.

The United States joined the Hague Conference only after preparatory work on the treaty had been completed. Our representatives did not participate in the work of the Special Commission that produced the first draft. ${ }^{220}$ Our government's observations on that draft and accompanying report were hardly earthshaking; they were chiefly designed to clarify perceived ambiguities. ${ }^{221}$ More to the point, a comparison of the Special Commission's draft ${ }^{222}$ with the

214. See supra text accompanying notes 93-95.

215. The United States had sent observer delegations to the Eighth and Ninth Sessions of the Conference, in 1956 and 1960. See Nadelmann, Hague Conference, supra note 48, at 297-304.

216. See 1967 SENATE DoCUMENT, supra note 154, at 20 (Report of the U.S. Delegation); 1967 SENATE REPORT, supra note 154, at 7 (statement of Richard D. Kearney); id. at 9 (statement of Joe C. Barrett); id. at 11 (statement of Philip W. Amram); see also 1967 SENATE DoCUMENT, supra note 154 , at 8 (letter of submittal) ("The most significant aspect of the convention is the fact that it requires so little change in the present procedures in the United States, yet at the same time requires such major changes, in the direction of modern and efficient procedures, in the present practices of many other states."); id. at 1 (letter of transmittal).

217. "It is, I think, a handsome compliment to the Congress of the United States and to the farsightedness of Public Law 88-619 that every basic change in procedure which the convention may require is a change in the direction of our procedure." 1967 SENATE REPORT, supra note 154, at 11 (statement of Philip W. Amram).

218. See 1967 SENATE DOCUMENT, supra note 154, at 20 (Report of the U.S. Delegation) ("profoundly affected the ultimate text of the convention"); 1967 SENATE REPORT, supra note 154, at 6 (statement of Richard D. Kearney); id. at 11 (statement of Philip W. Amram) ("profound effect").

219. See supra text accompanying notes $67-68$.

220. See Kearney, supra note 154, at 1-4.

221. See ACTES ET DOCUMENTS, supra note 153, at 127-29.

222. Id. at $112-16$. 
final treaty ${ }^{223}$ belies the notion that our unilateral efforts "profoundly affected the ultimate text of the convention." 224

The major innovations of the Service Convention were the creation of the Central Authority mechanism (coupled with the obligation of a designated Central Authority to effect service) and the restriction of judgments entered without notice. Both were features of the Special Commission's draft, ${ }^{225}$ as they are of the final treaty. ${ }^{226}$ So too were the obligation of a Central Authority to serve in a special manner requested by the applicant ${ }^{227}$ and provisions for optional channels of service. ${ }^{228}$ Of course, there were changes made in the Special Commission's draft, but the basic structure and most important features of the treaty were in place before the United States entered the game. ${ }^{229}$ Recalling the representations made to the Senate, it appears that the major concession that our negotiators obtained was the continued unilateral ability to provide more generous assistance to foreign litigants and tribunals than the treaty required. ${ }^{230}$ One thing we gave up, although it is not easy to

223. Id. at 345-55.

224. 1967 SENATE DOCUMENT, supra note 154, at 20 (Report of the U.S. Delegation).

225. See ACTES ET DoCUMENTS, supra note 153, at 112-13 (Draft Articles 2, 4-6); id. at 114-15 (Draft Articles 13-16).

226. See id. at 345-47 (Articles 2, 4-6); id. at 349-50 (Articles 15-16).

227. Compare id. at 113 (Draft Article 6) with id. at 346 (Article 5). But see 1967 SENATE DOCUMENT, supra note 154, at 20 (Report of the U.S. Delegation) ("In order to be sure that U.S. requirements of due process are met ... article 5 of the convention permits the issuing authority to request service in a particular manner ... and requires the state addressed to follow that manner unless it is incompatible with its internal law.").

228. Compare ACTES ET DOCUMENTS, supra note 153, at 114 (Draft Article 10) with id. at 348 (Article 10).

229. Mr. Kearney's subsequent description appears more accurate than the representations made to the Senate.

Public Law 88-619 was, however, in a number of respects more liberal in providing judicial assistance than the draft convention, which put the U.S. delegation in the pleasant position of being able to accept the proposed procedure and to concentrate on eliminating restrictions on its use. These efforts were reasonably successful ....

Kearney, supra note 154 , at 4 . He went on to mention two particular features of the Convention, the "freedom of using channels of transmission other than the Central Authority," id. at 4, and "certain substantive provisions having a due process character," id. at 5 , that were part of the Special Commission Draft. But see infra text accompanying note 230 (Article 19).

Even Mr. Amram admitted, with respect to "the due process provisions of articles 15 and 16." that "the United States did not suggest their inclusion." 1967 SENATE REPORT, supra note 154, at 14.

230. The letter of submittal indicated that

Article 19, inserted at the request of the U.S. delegation, will preserve the full scope of Public Law 88-619. It provides:

To the extent that the internal law of a contracting State permits methods of transmission, other than those provided for in the preceding articles, of documents coming from abroad, for service within its territory, the present Convention shall not affect such provisions.

This article makes certain that there will be no change internally in the United States in the philosophy, policy, and procedures of Public Law 88-619 and that even though other countries may not offer as much as we do unilaterally, nothing now authorized by this act will be repealed or reduced in the event of ratification of the convention on the part of the United States.

1967 SENATE DOCUMENT, supra note 154, at 5 (letter of submittal). See 1967 SENATE REPORT, supra note 154 , at 2 . 
discover from reading the legislative history of the treaty's ratification, was some of the unilateral power asserted in, and in connection with, Federal Rule 4(i). ${ }^{231}$

The politics of advice and consent, or simply the egos of those involved, may explain the puffing (and its opposite) that occurred in communications to the Senate about the Service Convention. The primary U.S. negotiator had special reason to want to claim such influence on the Service Convention because, if true, it would vindicate the course taken by the Commission on International Rules of Judicial Procedure on the advice of the Advisory Committee that he chaired. ${ }^{232}$

More than twenty years have passed since the United States ratified the Service Convention, and we are just now seeking to clear up part of the mess that has been spawned in domestic litigation by ignorance of the treaty and uncertainty as to whether and when it is binding. ${ }^{233}$ Some of our treaty partners view with concern the Supreme Court's interpretation of the Service Convention in the Schlunk case, ${ }^{234}$ perhaps for the wrong reason. What should most concern our treaty partners is the apparent unwillingness of the Court in Schlunk to resort to the policies of the treaty, as it would a federal statute, to strike down inconsistent state (or federal) law. ${ }^{235}$ That bodes ill for the Court's willingness to invalidate the waiver of service mechanism in amended Rule 4(d) as applied to a foreign defendant. More important, the amendment itself bodes ill for our effective participation in international lawmaking. We had trouble admitting at the time that we conceded anything in the Service Convention. ${ }^{236}$ Now we may appear to be trying to eliminate those concessions unilaterally. ${ }^{237}$

2. The Hague Evidence Convention. The United States was playing catch-up at the session of the Hague Conference that adopted the Service Convention, not only because the foundation for that treaty had already been laid without its participation, but also because the whole experience of participating officially in such an endeavor was new. Four years later, when the Conference adopted the Evidence Convention, we could legitimately claim that the initiative had been ours and, indeed, that we had taken the lead in drafting. ${ }^{238}$ Moreover,

231. Although the letter of submittal states that "the provisions of the convention are in conformity with rule 4(i) of the Federal Rules of Civil Procedure regarding the service of process abroad," 1967 SENATE DOCUMENT, supra note 154, at 3; see id. at 7, elsewhere it notes that "articles 8 and 10 permit a contracting state to narrow the group of permissible channels other than the central authority." Id. at 5 .

232. See 1967 SENATE REPORT, supra note 154, at 10 (statement of Philip W. Amram).

233. See supra text accompanying notes $99,129-33$. Amendments to the Federal Rules will not help matters in the states except to the extent they use those rules as a model.

234. See Hague Conference on Private International Law: Special Commission Report on the Operation of the Hague Service Convention and the Hague Evidence Convention, 28 I.L.M. 1556, 1560-61 (1989) [hereinafter 1989 Report]; Pfund, supra note 1, at 176.

235. See Burbank, supra note 72 , at $1478-80$.

236. See supra text accompanying note 231 .

237. See supra text accompanying notes 122-24.

238. See Kearney, supra note 154 , at 8-10. 
in aid of the international process, we had firmly in place a domestic process for the provision of expert advice and political soundings to the State Department. The Secretary of State's Advisory Committee on Private International Law was established in $1964 .^{239}$ Both the Advisory Committee and a study group of experts were involved in the preparatory work leading up to the Eleventh Session of the Hague Conference, at which the Evidence Convention was adopted. ${ }^{240}$ In addition, our representative was rapporteur of the Conference's Special Commission on the Evidence Convention and of the Committee that considered the Special Commission's draft at the Eleventh Session. ${ }^{241}$ In retrospect, ours was not enlightened leadership.

The Evidence Convention has been a disappointment to many countries that ratified it and a source of controversy and friction. Intended, as was the Service Convention, to bridge gaps between the civil law and common law systems, the treaty has proved inadequate. A major problem concerns pretrial discovery, in which gaps exist even among common law systems. Some of the signatory states believe that the Evidence Convention is the exclusive means to seek evidence abroad, including through discovery. ${ }^{242}$ They were alarmed when, in Aérospatiale, the Supreme Court held that it is not exclusive and, therefore, does not prevent discovery under the Federal Rules of Civil Procedure. ${ }^{243}$ A prominent observer contends, on the other hand, that the Evidence Convention was not intended to apply to pretrial discovery at all. ${ }^{244}$ What accounts for such fundamental misunderstanding and disagreement?

For the United States, whatever the legal relevance of preratification congressional materials in treaty interpretation, ${ }^{245}$ a holding of exclusivity in Aérospatiale would have come as a shock. In seeking the Senate's advice and consent, proponents of the Evidence Convention stressed how little the United States would concede and how much other countries would have to change their

239. See id. at 1 ; Pfund, supra note 1 , at 168 .

240. See Kearney, supra note 154, at 8-9.

241. See Report of United States Delegation to Eleventh Session of Hague Conference on Private International Law, 8 L.L.M. 785, 805 (1969).

242. See 1989 Report, supra note 234, at 1565-64, 1569.

243. See Société Nationale Industrielle Aérospatiale v. United States Dist. Court for the So. Dist. of Iowa, 482 U.S. 522 (1987); supra text accompanying notes 197-207. The reaction was not limited to signatory states:

At the Special Commission meeting, a distinguished delegate from an important country was quite vigorous in assailing the Aérospatiale decision, because he felt it had seriously damaged, as a political matter, the prospects of his country adopting the Evidence Convention .... [A]fter Aérospatiale, leading politicians in his country, who had also supported the adoption of the Convention, have tended to view that decision as a message that the U.S. does not take its treaty obligations seriously.

Letter from Edwin R. Alley, Esq., to Hon. Joseph F. Weis, Jr., Chairman, Committee on Rules of Practice and Procedure, 2 (April 11, 1990) (copy on file with author).

244. See Lawrence Collins, The Hague Evidence Convention and Discovery: A Serious Misunderstanding?, 35 INT'L \& COMP. L.Q. 765,783 (1986).

245. See, e.g., Malvina Halberstam, The Use of Legislative History in Treaty Interpretation: The Dual Treaty Approach, 12 CARDozo L. REV. 1645 (1991). 
ways. ${ }^{246}$ The presentations followed the script, sometimes literally, that had been used successfully to sell the Service Convention. ${ }^{247}$ But although in context most of the representations relevant to the exclusivity question concerned, as does Article $27,{ }^{248}$ only the freedom to provide more generous assistance to others than the Convention requires, ${ }^{249}$ some of the rhetoric is difficult to cabin in that fashion. Thus, both the Senate and the U.S. bar were told that the Evidence Convention "requires no major changes in United States legislation or rules." 250

Whatever their intended scope, such representations were not likely to induce belief in the exclusivity of the Evidence Convention. Yet, in light of the unilateral steps that the United States had taken in 1964, after Aérospatiale other countries must wonder what benefit they derived from us in the treaty. ${ }^{251}$ A number of Special Commissions have considered practice and problems under the Evidence Convention since it came into force. ${ }^{252}$ At the first such meeting, there was apparently a consensus that the treaty suffers from bad draftsmanship. ${ }^{253}$ That is not the whole story.

The misunderstandings and disagreements that have marked interpretations of, and practice under, the Evidence Convention are attributable to inadequate education as much as to bad draftsmanship. It is a commonplace belief ${ }^{254}$ that treatymaking on matters of private international law, like judicial reform, "is no

246. See S. EXEC. Doc. A, 92d Cong., 2d Sess. iii (1972) (letter of transmittal) [hereinafter 1972 SENATE DocumENT]; id. at xi (letter of submittal); S. EXEC. REP. No. 92-25, 92d Cong., 2d Sess. 5 (1972) [hereinafter 1972 SENATE REPORT].

247. Compare 1967 SENATE DOCUMENT, supra note 154, at 1 (letter of transmittal) and 8 (letter of submittal) with 1972 SENATE DOCUMENT, supra note 246, at iii (letter of transmittal) and xi (letter of submittal).

248. Article 27 provides:

The provisions of the present Convention shall not prevent a Contracting State from-

(a) declaring that Letters of Request may be transmitted to its judicial

authorities through channels other than those provided for in Article 2;

(b) permitting, by internal law or practice, any act provided for in this Convention to be performed upon less restrictive conditions;

(c) permitting, by internal law or practice, methods of taking evidence other than those provided for in this Convention.

23 U.S.T. at 2569,847 U.N.T.S. at 246.

249. See 1972 SEnATE DoCUMENT, supra note 246, at vi, $\mathrm{x}$ (letter of submittal); id. at 11, 13, 19-20, 22, 39 (Explanatory Report); 1972. SENATE REPORT, supra note 246, at 2.

250. 1972 SENATE REPORT, supra note 246, at 5 (quoting Philip Amram's argument to the ABA's House of Delegates). But see Kuhn, supra note 199, at 1041 ("Amram's statement applies only to changes in United States laws on judicial assistance to foreign litigants seeking evidence in the United States.").

251. Although the Evidence Convention is a multilateral convention, this perspective may nevertheless be reasonable given the amount of international civil litigation in the United States and our initiative in proposing the Evidence Convention. See Kuhn, supra note 199, at 1039-40.

252. See 1989 Report, supra note 234. For earlier reports, see 17 I.L.M. 1417 (1978); 24 I.L.M. 1668 (1985).

253. See Report of the United States Delegation to the Special Commission on the Operation of the Convention of 18 March 1970 on the Taking of Evidence Abroad in Civil or Commercial Matters, 17 I.L.M. 1417, 1428 (1978).

254. See Pfund, supra note 1, at 170; Kearney, supra note 154, at 3. 
sport for the short-winded."255 But the Evidence Convention was a sprint. Flush with the supposed success of the Service Convention, the United States proposed a treaty on taking evidence abroad in 1967. The treaty was adopted in October 1968. ${ }^{256}$ The intervening time was insufficient for the process of mutual education necessary for informed cooperation. ${ }^{257}$ In particular, it was insufficient time to educate representatives of other countries about our unique system of pretrial discovery and to reach accord about the effect the proposed treaty would have on it. Indeed, misunderstanding on that score has continued long after the treaty entered into force. ${ }^{258}$

There may have been sufficient legal reasons for the Supreme Court to hold that the Evidence Convention is not exclusive, ${ }^{259}$ but neither Article 27 nor the desire to preserve the integrity of the Federal Rules of Civil Procedure was one of them. ${ }^{260}$ Moreover, although the Court's expressed disbelief that our treatymakers would have surrendered unilateral power ${ }^{261}$ is understandable in context, it has not helped international cooperation. Reasoning of that sort can be infectious, furnishing a spurious interpretive prop to others engaged in domestic lawmaking ${ }^{262}$ and making it appear to other countries that the United States will play the game only if it never loses.

The Special Commissions of the Hague Conference that have considered experience under the Service and Evidence Conventions have done more than expose continuing misunderstanding. They have demonstrated that fruitful dialogue is possible. ${ }^{263}$ It is a pity, therefore, that during the recent effort to amend the Federal Rules of Civil Procedure, the rulemakers refused to heed suggestions, including one from the executive branch, that we take up

255. ARThur T. VANDERbiLt, Minimum Standards of Judicial AdMinistration xix (Arthur T. Vanderbilt ed., 1949). But see Stephen B. Burbank, Of Rules and Discretion: The Supreme Court, Federal Rules and Common Law, 63 NOTRE DAME L. REV. 693, 717 (1988) ("[B]ut often the quip more accurately describes the time it takes to sell a proposed reform than the time invested in conceiving it.").

256. Kearney, supra note 154 , at $8-9$. "The speed of this operation is unprecedented in the private law field." Id. at 9.

257. "The actual negotiation of treaties must be preceded by a campaign of reciprocal education by our bar and those of the civil law countries." Jones, supra note 6, at 560 . See also Jones, supra note 37 , at $96-97$.

[Varying perspectives] may even remain unconscious, and creep out of the dark quite unexpectedly after the treaty is born. Differences of view . . . on (existing) United States civil proceedings for discovery abroad only appeared after this treaty had been in force for several years; one will find little or nothing in the treaty's history pointing to any awareness of these differences in perspective.

J.H.A. van Loon, The Hague Conventions on Private International Law, in THE EFFECT OF TREATIES IN DOMESTIC LAw 221, 225 (Francis G. Jacobs \& Shelley Roberts eds., 1987).

258. See Pfund, supra note 1, at 174; 1989 Report, supra note 234, at 1565-64.

259. See Société Nationale Industrielle Aérospatiale v. United States Dist. Court for the So. Dist. of Iowa, 482 U.S. 522, 534-35 \& n.15 (1987). But see Kuhn, supra note 199, at 1036-41 (presenting five arguments against the Court's conclusion of nonexclusivity).

260. See supra text accompanying notes 196-201.

261. See Aérospatiale, 482 U.S. at 536-37; supra text accompanying note 200.

262. See supra text accompanying notes $140-41,195$.

263. See van Loon, supra note 257, at 243; Georges A.L. Droz \& Adair Dyer, The Hague Conference and the Main Issues of Private International Law for the Eighties, 3 Nw. J. INT'L L. \& BUS. 155, 166-67 (1981). 
controversial interpretive positions that underlie domestic reform proposals at the Hague Conference rather than unilaterally impose them. ${ }^{264}$

\section{III}

\section{COMMON APPROACHES AND ATTITUDES: UNILATERALISM, NATIONAL UNIFORMITY, IMPATIENCE, AND PENURIOUSNESS}

\section{A. Unilateralism and National Uniformity}

For most of our history, federal lawmakers have not provided for the special needs and characteristics of procedure in international civil litigation, either unilaterally or through international agreements. Federal legislation as to matters of procedure in general has been episodic. ${ }^{265}$ The authors of the original Federal Rules of Civil Procedure made only minor provisions for international civil litigation, ${ }^{266}$ and the federal courts have usually conflated international with domestic litigation in fashioning judge-made procedural law. ${ }^{267}$ Finally, until 1964, the United States declined to become involved in international efforts to address conflicts in procedural law. ${ }^{268}$

One major factor that helps explain the historic dearth of congressional legislation and absence of treaties on procedure for international civil litigation is concern for the lawmaking prerogatives of the states. To the extent that either the Constitution or domestic politics was thought to prevent federal action, the necessary result was that, from an international perspective, the United States acted (if at all) unilaterally, even if not with one voice. ${ }^{269}$

Concerns about the lawmaking prerogatives of the states have not been the only cause of unilateralism in procedural lawmaking for international civil litigation, however. Ours is a history of isolationism and of strong preference for domestic solutions. ${ }^{270}$ The Federal Rules represented a triumph over claims of federalism for the procedural law applied in the federal courts. But the animating goal of uniformity, as implemented by the rulemakers and by the federal courts in judge-made law, militated against special rules for international civil litigation. The centrifugal force of a norm of national uniformity and of legal chauvinism also rendered the pursuit of international uniformity more difficult. $^{271}$

In the relatively brief span of years since Congress created the Commission and Advisory Committee on International Rules of Judicial Procedure, a

264. See, e.g., Executive Branch Comments, supra note 106, at 3-4. Moreover, the rulemakers proceeded with the amendment to Rule 4 extending the waiver of service mechanism to international civil litigation before the State Department had the opportunity to conduct a survey of foreign government views. See supra text accompanying note 128 .

265. See supra text accompanying notes 16-34.

266. See supra text accompanying notes 74-77.

267. See supra text accompanying notes 180-207.

268. See supra text accompanying note 1 .

269. See supra text accompanying notes 7-9.

270. See supra text accompanying notes 5-6.

271. See supra text accompanying notes $74-77,180-87$. 
dramatic change has occurred in the United States's formal posture towards procedural lawmaking for international civil litigation. There is, however, less there than meets the eye. The Commission's recommendations of unilateral changes in the U.S. rules regarding judicial assistance in 1963 and 1964 were initially a consequence of its own vicissitudes and ultimately reflected the naive view that if the United States were generous, other countries would follow its lead. ${ }^{272}$ Moreover, that approach was in tension if not conflict with the position already taken by Congress when it established the Commission and set its priorities. ${ }^{273}$ Finally, grants of unilateral assistance were matched with claims of unilateral power. ${ }^{274}$. The United States announced at the time that no strings were attached to its generosity. ${ }^{275}$ Subsequent events suggest that there is more than one way to attach strings and, more generally, that unilateralism is a hard habit to break. ${ }^{276}$

There was little U.S. negotiators could do to affect the structure and major features of the Service Convention, but that did not prevent them from making extravagant claims in seeking Senate consent to the treaty. Their major accomplishment seems to have been the preservation of freedom for countries to offer more generous judicial assistance than required by the Convention. ${ }^{277}$ That was also a goal in drafting and negotiating the Evidence Convention. The claims made in selling that treaty were similar in tone and content. ${ }^{278}$ The domestic message on both occasions seemed to be that the United States can

272. See supra text accompanying notes 48-61, 80-82; Fourth Annual Report, supra note 58, at 9, 11 ; Harry L. Jones, Commission on International Rules of Judicial Procedure, 8 AM. J. CoMP. L. 341, 344 (1959). But see Philip W. Amram, Public Law No. 88-619 of October 3, 1964 -New Developments in International Judicial Assistance in the United States of America, 32 J. BAR Ass'N OF D.C. 24, 25, 33 (1965) (suggesting that initial decision to concentrate on unilateral reforms not driven by timing and funding concerns).

In seeking more money for the Commission in 1965, Senator Morse observed:

As valuable as these revisions of our rules and statutes are, they do little to improve the judicial assistance available to litigants in courts of the United States and in our State courts. That can only be achieved by the negotiation of the procedural treaties which the Congress has directed the Commission to draft.

111 CONG. REC. 8532 (1965).

273. See 103 CONG. REC. 5727 (1957) ("Effective and uniform reform of international procedures can be brought about only by general international agreement."); supra text accompanying notes 39 , 49, 61; supra note 95. But see Fourth Annual Report, supra note 58, at 11 ("The Commission has not neglected this statutory responsibility .... [T] The drafting of international agreements should be deferred for the time being until the results of possible unilateral action can be determined.").

274. See supra text accompanying notes 72,92 .

275. See supra text accompanying note 66 .

276. As one commentator has noted, for example:

In Sociéte Nationale, the Court cited lack of reciprocity, but this country waived that objection in 1964 when changes in legislation and the Federal Rules opened the way for foreign litigants to secure evidence in this country freely. As Mr. Amram remarked, that step was taken without any requirement of reciprocity. We should not now be returning to that narrow approach.

Joseph F. Weis, Jr., The Federal Rules and the Hague Conventions: Concerns of Conformity and Comity, 50 U. PITT. L. REv. 903,932 (1989) (footnotes omitted). Cf. Bomstein \& Levitt, supra note 68, at 451 ([C]onsideration of reciprocity under 28 U.S.C. $\$ 1782$ "seems to be inconsistent with the purpose of the statute ....").

277. See supra text accompanying notes 215-36.

278. See supra text accompanying notes $238-63$. 
participate in the international arena without giving up the power to act unilaterally whether in aid of litigation at home or abroad.

That is also a message treaty partners of the United States might reasonably take from Supreme Court decisions interpreting the Service and Evidence Conventions. Even if the Court reached the correct treaty interpretations in Schlunk and Aérospatiale, it employed reasoning that could deny to treaties regulating procedure in international civil litigation the power to constrain unilateral action. ${ }^{279}$ Thus, in Schlunk the Court said that it was unwilling to believe that "this country, or any other country; will draft its internal laws deliberately so as to circumvent the Convention."280 . In Aérospatiale, the Court manifested more interest in preserving the policies of the Federal Rules of Civil Procedure than it did in adjusting domestic law to the policies of a treaty. $^{281}$

The recent effort to amend the Federal Rules of Civil Procedure with respect to the needs of international civil litigation is more of the same. The amendments to Rule 4 are said to be animated in part by a desire to give more prominence to, and foster compliance with, the Service Convention and other international agreements regulating service. ${ }^{282}$ Although they would thus mark an advance, in taking one step forward we are also taking two steps back.

Coming so soon after Schlunk, the extension of the waiver of service mechanism abroad may be viewed by other signatories of the Service Convention as a response to an invitation, rather than as proof that the Court was a poor prophet, regarding the use of internal law to circumvent treaties. ${ }^{283}$ In any event, the effect of the amendment will be to recapture unilaterally some of the power that we surrendered in the Service Convention, ${ }^{284}$ all in the name of national uniformity (in the federal courts). In the case of amended Rule 4 (f)(3) (providing for alternate methods of service upon order of the court), the trade-offs are less obvious, due in large part to the drafting history. The mischief now reposes in the Advisory Committee Note, which advances interpretations of the Service Convention that call into question the genuineness of a professed commitment not to violate treaties. ${ }^{285}$

The proposed amendment to Rule 26 is gone, but it may not be soon forgotten. Originally an attempt to adjust domestic law to the policies of the Evidence Convention, the proposal quickly became mired in controversy. It emerged from the first round barely comprehensible, and although eventually

279. See supra text accompanying notes 196-99; see also United States v. Alvarez-Machain, 112 S. Ct. 2188, 2198 n.4 (1992) (Stevens, J., dissenting) ("It is difficult to see how an interpretation that encourages unilateral action could foster cooperation and mutual assistance-the stated goals of the Treaty.").

280. Volkswagenwerk Aktiengesellschaft v. Schlunk, 486 U.S. 694, 705 (1988). See supra text accompanying note 237 .

281. See Société Nationale Industrielle Aérospatiale v. United States Dist. Court for the So. Dist. of Iowa, 482 U.S. 522, 542-43 (1987); Burbank, supra note 72, at 1493-94.

282. See 1993 Amendments, supra note $118,113 \mathrm{~S}$. Ct. at 632 ; supra text accompanying note 133.

283. See supra text accompanying notes 119-24.

284. See supra text accompanying notes 234-37.

285. See supra text accompanying notes 143-69. 
clarified in the second, might have been thought to claim more unilateral power than it foreswore. ${ }^{286}$

In sum, unilateral lawmaking was the only course open to the United States until it overcame the federalism and other objections to international cooperation. By that time, however, ingrained chauvinism was buoyed at the federal level by a normative preference for uniform rules. The rhetoric attending the United States's first forays into the world of international procedural lawmaking suggested that it could participate at no, or very little, cost to the established regime. That has been the tendency of U.S. procedural lawmaking, international and domestic, ever since.

Whether or not unilateralism was initially a principled choice of the Commission and Advisory Committee on International Rules of Civil Procedure, ${ }^{287}$ it was the preference of Professor Smit, who became an important contributor to the Commission's work. ${ }^{288}$ Indeed, it remains his preference today. ${ }^{289}$ That preference is consistent with this country's traditional approach to international relations but is hard to justify, even in purely practical terms, in a world that is increasingly interdependent and in which our economic strength is waning.

Unilateral lawmaking can, of course, lead to international rapprochement, if not international cooperation, as the history of aggressive assertions of legislative jurisdiction to enforce U.S. antitrust law may suggest. ${ }^{200}$ But if unilateral claims of power are to lead to international accord, they require both the strength to persevere in the face of international objections and an eventual perception on the part of other countries that it is in their best interests to follow suit. Although the first condition may obtain in connection with procedural law for international civil litigation, the second seems remote. Most other countries do not share our views about litigation, ${ }^{291}$ and as we ourselves reconsider those views, ${ }^{292}$ they have even less incentive to emulate us.

Moreover, unilateralism can work in two directions, conferring as well as seeking to appropriate benefits. The problem with unilateral generosity is that it may weaken U.S. bargaining power when, other countries having chosen not to follow our example, it attempts to work out mutually acceptable agree-

286. See supra text accompanying notes $170-79$.

287. See supra text accompanying notes 48-61, 80-82, 272.

288. See Smit, supra note 72, at 1015-16, 1018-19, 1046; see also Amram, supra note 272.

289. See Hans Smit, International Control of International Litigation: Who Benefits?, 57 LAW \& CONTEMP. PROBS. 25 (Summer 1994) [hereinafter International Control]; Hans Smit, Les Conflits de Juridiction en Procédure Civile, 1990 Revue Internationale De Drort Comparé, No. 3, 872 [hereinafter Les Conflits].

290. See Gary B. Born, A Reappraisal of the Extraterritorial Reach of U.S. Law, 24 L. \& POL'Y INT'L Bus. 1, 67-68 (1992); Friedrich K. Juenger, Constitutional Control of Extraterritoriality?: A Comment on Professor Brilmayer's Appraisal, 50 LAw \& CoNTEMP. ProBs. 39, 46 (Summer 1987).

291. See Mauro Cappelletti \& Bryant Garth, $A$ Comparative Conclusion, in 16 INTERNATIONAL ENCYClOPEDia of CoMPARATIVE LAW 6-436 (Mauro Cappelletti ed., 1984).

292. See Burbank, supra note 76, passim. 
ments. ${ }^{293}$ That looms as a difficulty for the United States in pursuing a multilateral convention on the recognition and enforcement of foreign judgments. ${ }^{294}$

Renouncing adherence to the Service and Evidence Conventions, which Professor Smit advocates, ${ }^{295}$ would at least be a straightforward way of implementing a strategy of unilateralism. For that reason alone, it would be preferable to the rulemakers' present course, ${ }^{296}$ a course encouraged by Supreme Court decisions that are instinct with a preference for domestic law and, in the case of federal courts, for national over international uniformity. ${ }^{297}$ Renunciation would also be preferable because it would require decisions by those charged with the responsibility to conduct this country's foreign relations. Because courts and rulemakers have neither mandate nor expertise in that sphere, unilateral judicial lawmaking on matters that obviously and necessarily implicate foreign relations is subject to criticism, whether it would confer or seek to appropriate benefits. ${ }^{298}$

Far from renouncing the Service and Evidence Conventions, however, we should work harder with our treaty partners to understand and remove sources of difficulties. That will require a greater commitment of time and resources than we have thus far been willing to devote to the enterprise, and it will also require greater willingness to entertain the notion that the U.S. way is not the only rational way to proceed. ${ }^{299}$ Equally important, an effort to understand and remove the sources of present difficulties under the Service and Evidence Conventions will require greater institutional coordination among domestic lawmakers. ${ }^{300}$ Such coordination is necessary both to prevent unilateral lawmaking that would compromise international cooperation and to insure that any attempts to reach new understandings-an endeavor that should be a high priority in the case of the Evidence Convention ${ }^{301}$-are fully informed.

\section{B. Impatience}

The Commission and Advisory Committee on International Rules of Judicial Procedure wanted to accomplish something in the short time originally allotted to their work, and that period was not sufficient to complete the task that Congress set as the first priority: "draft[ing] for the assistance of the Secretary of State international agreements to be negotiated by him."

293. See Burbank, supra note 72, at 1480. But see Smit, International Control, supra note 289 , at 34 ("better to put domestic law in optimum shape before seeking to negotiate a treaty or treaties").

294. See supra text accompanying note 5.

295. See Smit, International Control, supra note 289, at 44-45; Smit, Les Conflits, supra note 289, at $880,882,883$.

296. See supra text accompanying notes $99-179$

297. See supra text accompanying notes 197-201, 234-36, 259-62, 281-83.

298. See infra text accompanying notes 329-46.

299. See infra text accompanying notes 315-27, 362-67.

300. See infra text accompanying notes 356-61.

301. See Born, supra note 171, at 101-02.

302. Act of Sept. 2, 1958, Pub. L. No. 85-906, § 2, 72 Stat. 1743. See supra text accompanying note 39. 
sion lost some freedom of action, even though more time and money became available, but there was always hope that success in the first phase might prompt greater public support for the second. ${ }^{303}$ Success required that the first phase be implemented even over the complaints of those who "objected that a more civilized and clearer way of handling the whole question would be by concluding specific bilateral or other arrangements with . . . foreign countries on the matter of so-called 'judicial assistance." 304

When the United States joined the Hague Conference in 1964, it had the opportunity to test whether, in fact, our recent unilateral lawmaking would "inhibit efforts to achieve international arrangements." 305 The Service Convention was no test at all, because we came on the scene so late in its development. Yet, in the domestic process of ratification, "success" was defined according to the extent of unilateral power preserved. ${ }^{306}$ That attitude, the attendant conviction that the United States's system alone is worth emulating, and the short time devoted to drafting and negotiating the Evidence Convention, hindered mutual education and understanding. ${ }^{307}$ The 1964 legislation may have brought "the United States to the forefront of nations adjusting their procedures to those of sister nations," ${ }^{308}$ but the adjustments were unilateral. Having given so much, we were not willing to take the time necessary to understand other legal systems and legal cultures, or to educate representatives thereof about our own.

The impatience of U.S. lawmakers thus had at least two aspects: a desire to push ahead with reforms we deemed appropriate and an unwillingness to come to grips with the underlying assumptions and animating policies of legal arrangements in other countries. Subsequent events have confirmed that the integrity of domestic law, in particular the Federal Rules of Civil Procedure, is more important to the United States than accommodating the needs of the international legal order. That was one of the messages of the Supreme Court's decision in Aérospatiale ${ }^{309}$ and it seems to have been received loud and clear by the lower federal courts, ${ }^{310}$ while the rest of the Court's opinion has been relegated to the dustbin of U.S. rhetoric on international cooperation. ${ }^{311}$ It is

303. See supra text accompanying notes $52-53,61,80-84,287-89$.

304. Kaplan, supra note 75 , at 636 . Professor Smit asserts that "[a]t no time was consideration given to drafting conventions in the areas addressed by the Project and the Commission." Smit, International Control, supra note 289 , at 33 n.48. The record does not support this assertion. See, e.g., supra notes $272-73$ and accompanying text.

305. Kaplan, supra note 75, at 636. See supra text accompanying notes 95, 214.

306. See supra text accompanying notes $215-32$.

307. See supra text accompanying notes 238-58.

308. S. REP. No. 1580, 88th Cong., 2d Sess. 2 (1964). See supra text accompanying note 66.

309. See supra text accompanying notes 196-207, 281.

310. See Stephen F. Black, United States Transnational Discovery: The Rise and Fall of the Hague Evidence Convention, 40 INT'L \& COMP. L.Q. 901, 906 (1991); Born, supra note 171, at 86-90.

311. See Bruce Zagaris, Developments ir: International Judicial Assistance and Related Matters, 18 DEN. J. INT'L L. \& POL'Y 339 (1990).

To be successful, diplomacy must have legitimacy. To establish legitimacy often requires time and forceful marshalling of evidence and argument. To short cut the process and try to impose realpolitik may be counterproductive. Treaties and international assistance remain 
also a message other countries, including the United States's treaty partners, may take from the recent process to amend the Federal Rules of Civil Procedure. ${ }^{312}$ The rulemakers are pursuing a vision of domestic justice at the expense of international justice.

\section{Penuriousness}

The Commission on International Rules of Judicial Procedure's attempts to secure adequate funding from Congress make for depressing reading. ${ }^{313}$ The work that the Commission accomplished resulted primarily from private funding, and, perhaps in part for that reason, the Commission did not follow Congress's stated priorities. ${ }^{314}$

Once the United States determined to participate in efforts to reach international agreements in the area of private international law by joining the Hague Conference and other similar organizations, it remained to be seen whether those commitments would be backed up with the resources necessary for effective participation. The record is mixed. It has improved, but there is still progress to be made.

The United States has financial obligations to the Hague Conference and other similar international organizations to which it belongs. Unfortunately, the politics of certain international organizations has in the past caused this country to treat all such organizations monolithically, reducing or delaying our payments. ${ }^{315}$ Private international law, including procedure, is not without a political component, but it is far removed from the concerns that caused us to cut back on funding. ${ }^{316}$ The United States needs to be more discriminating in the future, mindful that other members are likely to see in the failure to pay our dues a lack of serious commitment to the enterprise.

The drafting and negotiating of treaties requires an infrastructure within domestic institutions. For initiatives in private international law, the Department of State relies on the Office of the Legal Adviser, the Secretary's Advisory Committee on Private International Law, and ad hoc groups of experts. ${ }^{317}$ This system, both in formulating the United States's positions and in seeking

areas in which developments in enforcement have the most potential because no large country other than the U.S. has so few treaties and yet so much rhetoric about international cooperation.

Id. at $384-85$.

312. See supra text accompanying notes $123-28$.

313. See, e.g., Hearings Before Subcommittees of the House Committee on Appropriations, 89th Cong., 1st Sess., Part 1, at 201-23 (1965).

314. See supra text accompanying notes $48-49,61$.

315. See Harold S. Burman \& Peter H. Pfund, Review of Developments from May 1990 to August 1991, at 15-16 (unpub. manuscript on file with author).

316. See id. But see Hearing on H.J. Res. 732 Before the Subcomm. on Int'l Organizations and Movements of the House Committee on Foreign Relations, 88th Cong., 1st Sess. 53-54 (1963) [hereinafter Hague Hearing] ("[E]very organization we belong to is not only a technical organization but a political organization, and our delegates have to be prepared to carry on a political fight.").

317. See, e.g., Kearney, supra note 154, at 1, 8; Pfund, supra note 1, at 168. 
ratification of concluded treaties, places heavy reliance on the private sector. ${ }^{318}$ That emphasis appears to reflect the views that, in matters of private law, the government's role is to seek to implement the preferences of U.S. legal consumers (including government consumers), and that success in securing the consent of the Senate depends on the enthusiasm of, and lack of serious disagreements among, those consumers. ${ }^{319}$ Viewing the enterprise as driven by the private sector permits, or at least helps to justify, heavy reliance on private resources to fund the work. ${ }^{320}$

In the early years of U.S. involvement in the work of the Hague Conference and other similar organizations, the responsibility for private international law work rested with a designated individual within the State Department's Office of the Legal Adviser. ${ }^{321}$ Since 1979, there has been a separate Office of the Assistant Legal Adviser for Private International Law charged with those responsibilities. That office now has two full-time professionals, an administrative assistant, and occasional student interns. Their responsibilities are varied: monitoring developments under the private international law treaties to which the United States is a party; coordinating attempts to secure ratification of such treaties signed on behalf of the United States; organizing and chairing study groups to consider new treaty initiatives; and participating in international meetings for the purpose of negotiating treaties and discussing experience under treaties already concluded. ${ }^{322}$

Both the Secretary's Advisory Committee and its associated study groups are composed primarily (although by no means exclusively) of lawyers and academics from the private sector who participate without compensation and often without reimbursement of expenses. ${ }^{323}$ Funds for meetings both at home and abroad are limited, and it requires careful planning and creativity on the part of the Office of the Assistant Legal Adviser for Private International Law, as well as generosity on the part of private sector participants, to ensure that the United States is adequately represented..$^{324}$

It is no criticism of the Office of the Assistant Legal Adviser for Private International Law to say that the public support provided for the work of that office is inadequate. On the contrary, the volume and quality of the work accomplished are extraordinary. But there are only twenty-four hours in a day, and, as the United States increases its private international law commitments, ${ }^{325}$ the setting of priorities will become more painful and the costs of

318. See Hague Hearing, supra note 316, at 10; Peter H. Pfund, United States Participation in International Unification of Private Law, 19 INT'L LAW. 505, 508-510, 517-19 (1985); Pfund, supra note 1 , at $168,180-81$.

319. See Pfund, supra note 318 , at $508,518$.

320. See Kearney, supra note 154, at 16; Pfund, supra note 318, at 509. Cf. Nadelmann, supra note 48, at 299, 302 (1956 and 1960 observer delegations to Hague Conference did not receive government funds).

321. See Kearney, supra note 154.

322. Interview with Peter H. Pfund (August 26, 1992) [hereinafter August 1992 Pfund Interview].

323. Id. See Pfund, supra note 318, at 509.

324. August 1992 Pfund Interview, supra note 322.

325. See Pfund, supra note 1 , at 178-80. 
tasks deferred or simply not addressed will become unacceptable. The problem may not be unique to this office, which must compete for resources with other elements of the State Department. The dollars required for one or two more professionals in the office and for adequate participation in domestic and international meetings are, however, a small price to pay when the stakes are this country's effectiveness in an increasingly important field of international lawmaking.

The United States has interests in private international law that transcend, and may even conflict with, the collective preferences of U.S. legal consumers. Federal and state governments devote substantial resources to the establishment and maintenance of court systems. In addition, the resolution of international disputes and the establishment of behavioral norms for international actors is increasingly critical to our economic and social well-being as a nation. There is no bright line between public and private law, ${ }^{326}$ a fact that both complicates the work of reaching international agreements on matters of private international law $^{327}$ and highlights the importance of adequate public support for the enterprise.

\section{IV}

\section{INSTITUTIONAL IMPLICATIONS}

The recent history of U.S. involvement in procedural lawmaking for international civil litigation reveals pervasive tension between the desire to honor international agreements and the determination to do justice as we see it. In resolving that tension, we have too often preferred to act rather than discuss, to act unilaterally rather than cooperatively, and to pursue national rather than international uniformity. Professor Smit's proposal that we renounce adherence to the Service and Evidence Conventions is at least forthright. ${ }^{328}$ Sharing the view that the United States should conduct itself forthrightly in the international arena, I believe that both normative and practical considerations argue for more rather than less international cooperation. If that is correct, there must be a greater commitment of time and resources to the enterprise. More fundamentally, there must be some adjustments in lawmaking structures and techniques.

\section{A. Legislation and Court Rulemaking}

The arguments traditionally made in support of the control of procedure by court rules rather than legislation include institutional authority, expertise, and efficiency. ${ }^{329}$ In recent years, federal court rulemaking has attracted consider-

326. See, e.g., Symposium, The Public/Private Distinction, 130 U. PA. L. REV. 1289 (1982).

327. See Juenger, supra note 290 , at 46 ; Pfund, supra note 318 , at 507.

328. See supra text accompanying note 297.

329. See, e.g., Roscoe Pound, Regulation of Judicial Procedure by Rules of Court, 10 ILL. L. REV. 163 (1915); Owen J. Roberts, Trial Procedure-Past, Present and Future, 15 A.B.A. J. 667 (1929). 
able attention and generated substantial controversy. ${ }^{330}$ Congress's overhaul of the Enabling Acts ${ }^{331}$ has not succeeded in quieting the criticism. ${ }^{332}$ In large part, that is due to growing awareness of the political dimensions of procedural reform, ${ }^{333}$ an awareness fueled by Congress's own forays into the field. ${ }^{334}$ When proposed Federal Rules require choices between procedural and substantive policies, including by reason of their anticipated effects, claims for rulemaking founded in the judiciary's institutional authority and expertise are of diminished force, as are claims for trans-substantive procedural law. ${ }^{335}$ Moreover, changes in the rulemaking process, ${ }^{336}$ assimilating it to the legislative process, have sapped claims of comparative efficiency, and Congress's renascent interest in procedural reform has weakened the argument concerning that body's traditional inertia.

International civil litigation in U.S. courts is sufficiently ubiquitous that, in one sense, every proposed change in domestic procedure has international implications. Very few such proposals, however, necessarily and obviously implicate U.S. foreign relations. The biggest subset is likely to be proposals that deal with matters that are the subject of international agreements. When proposed procedural lawmaking necessarily and obviously implicates U.S. foreign relations, there is no persuasive theoretical or practical argument for court rulemaking in its present form.

Court rulemaking under the Enabling Act does not require or even contemplate congressional approval, and it gives no role at all to the President (except insofar as blocking proposed Federal Rules requires legislation). ${ }^{337}$ Moreover, such congressional review as has occurred both of specific proposals and of the rulemaking process has usually been at the initiative of the House of Representatives. ${ }^{338}$ In other words, the enterprise is one in which the institutions primarily charged with the conduct of this country's foreign relations play either no role at all or a very minor (and reactive) role. For procedural law of the sort under discussion-necessarily and obviously implicating U.S. foreign relations - the perspective of institutional authority does not support the current process of creating Federal Rules. ${ }^{339}$

330. See, e.g., 1985 HOUSE REPORT, supra note 30, at 12-14; supra text accompanying notes 29-30.

331. Act of Nov. 19, 1988, Pub. L. No. 100-702, 102 Stat. 4642, 4648-52; see supra text accompanying notes $31-32$.

332. See, e.g., Burbank, supra note 72 , at 1484-90, 1494-96.

333. See, e.g., Burbank, supra note 34, at 849; Burbank, supra note 76, at 1934-41; Burbank, supra note 255 , at $713-19$.

334. See supra text accompanying notes 33-34.

335. See, e.g., Stephen B. Burbank, Proposals To Amend Rule 68-Time to Abandon Ship, 19 U. MICH. J.L. REF. 425 (1986).

336. See 28 U.S.C. $\$ 2073$ (1988).

337. See id. $\$ \S 2072,2074$. An exception in section 2074(b) requires that "[a]ny such rule creating, abolishing, or modifying an evidentiary privilege shall have no force or effect unless approved by Act of Congress."

338. See 1985 HoUSE REPORT, supra note 30, at 4-19.

339. Cf. David J. Gerber, Obscured Visions: Policy, Power, and Discretion in Transitional Discovery, 23 VAND. J. TRANSNAT'L L. 993 (1991) (criticizing extensive judicial discretion in transnational discovery). Many of Professor Gerber's arguments and much of his analysis are equally applicable to 
Unlike the Commission and Advisory Committee on International Rules of Judicial Procedure, ${ }^{340}$ the judges (including Justices), academics, and (very few) practicing lawyers who collectively comprise the group I refer to as "the rulemakers" have little experience or expertise in international civil litigation, let alone international law. ${ }^{341}$ The Advisory Committee's interpretations of the Service Convention in connection with the 1993 amendments to Rule 4 and the whole Rule 26 fiasco are not reassuring in that regard. ${ }^{342}$ The Supreme Court sent back proposals with foreign relations implications, and although some of them became effective as revised, it was not a speedy process. ${ }^{343}$

The rulemakers are bright, accomplished individuals who can learn what they do not know. Unfortunately, the Advisory Committee made no special effort to learn the views of experts in international relations and international law, including representatives of the State Department, apparently relying on a monolithic view of the government, and thus on the Justice Department, to convey those views. ${ }^{344}$ Moreover, when the State Department's views were finally made known, they were for a time dismissed or discounted as reactive or as a change of position. ${ }^{345}$ Against this background, the last-minute efforts of the Chairs of the Advisory and Standing Committees, which resulted in an important change in the amendments to Rule 4, are even more impressive, however irregular the procedure. ${ }^{346}$

When prudence counsels (or the Enabling Act requires) that federal law be made through legislation rather than court rules, the desire to take advantage of the rulemakers' expertise, to facilitate comprehensive procedural reform, to honor a sense of shared institutional authority, or to overcome traditional congressional inertia, may nonetheless suggest the wisdom of a two-tier process.

service of process abroad. Moreover, many of the considerations he adduces for curbing judicial discretion are equally apt when the question is not whether there should be rules but who should make them and pursuant to what process. See id. at 1006-09.

340. See supra text accompanying note 98.

341. In making this assertion, I have reviewed biographical material on each member of the Advisory Committee on Civil Rules and of the Standing Committee who was serving in June 1992 (biographical materials on file with author).

342. See supra text accompanying notes $148-79$.

343. See supra text accompanying notes 99-103.

344. The State Department's Office of the Assistant Legal Adviser for Private International Law did not initially receive a copy of the proposed amendments to the Federal Rules of Civil Procedure. "It was rather disquieting and embarrassing that the U.K. government was somehow more aware of these developments within the United States than was the State Department. The consequent need to catch up has not been comfortable for any of the agencies and persons involved." Pfund, supra note 128, at 160. The Legal Adviser's Office was apparently in the same position. See letter from Franklin R. Bay, Deputy Legal Adviser, to Joseph F. Spaniol, Jr., Secretary, Committee on Rules of Practice and Procedure (February 14, 1992) (copy on file with author). In requesting copies of pending and future proposed amendments "as a matter of routine," Mr. Bay observed:

Such notice would provide the Department the opportunity to help ensure that the effects of proposed amendments on international treaty obligations of the United States, U.S. ability to comply with the requirements of customary international law, and good international relations Id. at 2. of the United States with other countries may adequately be taken into account.

345. See supra text accompanying notes $134-36,142$.

346. See supra text accompanying notes 114-18. 
The weak version of such a process would require only that the rulemakers bring questionable exercises of authority to Congress's attention. ${ }^{347}$ The strong version would require legislation to implement the rulemakers' recommendations on such matters. ${ }^{348}$ Both versions would leave the initiative to formulate new or amended Federal Rules with the rulemakers.

Putting aside the rulemakers' lack of, and failure to seek out, international expertise, the recent amendments to Rule 4 presented a situation in which the strong version of a two-tier process, involving the active participation of the rulemakers, Congress, and the President on those proposals having necessary and obvious implications for foreign relations, would have been useful. The amendments involved a comprehensive revision of Rule 4; and service of process abroad was properly part of such an endeavor. The rulemakers' expertise was important but, particularly because treaties could be affected, it was not the only perspective needed. The Advisory Committee recognized that a proposal to extend the federal courts' territorial authority to adjudicate in federal question cases raised Enabling Act issues, and it flagged the matter for the Supreme Court and Congress. ${ }^{349}$ Given that the primary impact of that provision will come in international civil litigation, ${ }^{350}$ it is a shame that the Committee did not take a similar approach to other controversial provisions in Rule 4 that necessarily and obviously implicate this country's foreign relations. ${ }^{351}$ Better yet, legislation should have been sought on all such proposals, with the rest of the amendments to Rule 4 following the process prescribed by the Enabling Act. ${ }^{352}$

It is not just formal claims of institutional authority and expertise that prompt resistance to a two-tier process. The myth of trans-substantive procedure cannot accommodate rules that are differentiated on substantive or other grounds. Undifferentiated procedure in turn serves to protect judicial power by submerging policy choices and making it harder to identify issues for

347. This is exactly what the rulemakers have done in a "Special Note" to amended Rule 4, which reads: "Special Note: Mindful of the constraints of the Rules Enabling Act, the Committee calls the attention of the Supreme Court and Congress to new subdivision (k)(2). Should this limited extension of service be disapproved, the Committee nevertheless recommends adoption of the balance of the rule." 1993 Amendments, supra note 118, $113 \mathrm{~S}$. Ct. at 631-32. For the history of this "Special Note" and the proposal to which it relates, see Burbank, supra note 72 , at $1484 \mathrm{n} .164$. The current text of the provision is quoted supra note 143. See also infra text accompanying note 349.

348. See Burbank, supra note 8, at 1195 n.775.

349. See supra note 347.

350. See supra note 143.

351. In light of the history of the 1993 amendments to Rule 4, the Supreme Court was aware of the potential problems. See supra text accompanying notes 99-101. Moreover, the Court presumably sought to ensure such awareness in requesting a report about any proposals that were controversial. See supra note 177 . Congress may not have had the benefit of knowledge deriving from either the history or the report.

352. Legislation should have been sought for the extension of personal jurisdiction in federal question cases, see supra note 143, and the application of the waiver of service mechanism to international cases. See supra text accompanying note 104. Amended Rule 4(f)(3), supra text accompanying note 143 , is not on its face controversial for these purposes. Rather, it is the Advisory Committee Note that may cause problems. 
congressional attention. ${ }^{353}$ Those are reasons enough for Congress to require a two-tier process of the strong type when the rulemakers propose Federal Rules that necessarily intersect with an existing treaty. The existence of a treaty is an admittedly imperfect surrogate for a substantial foreign relations interest. But the requirement would at least ensure the active participation of Congress and the President in unilateral domestic lawmaking on matters where we have already made a national commitment to international cooperation. ${ }^{354}$ It would also provide an opportunity for Congress to consider whether a particular proposal should apply in state courts, an option not available to the rulemakers. $^{355}$

Even if the United States adopts a two-tier process of the strong type for rulemaking proposals that necessarily and obviously implicate foreign relations-and especially if we do not-the rulemakers need to put their house in order. It makes no sense to have them proceed through all or most of their deliberations in ignorance of foreign relations considerations (or foreign or international law), leaving to Congress the task of redoing the policy calculus after hearing and taking full account of those concerns.

Changes in the world and in the world of litigation may bring the concerns of international civil litigation to the attention of the rulemakers more often in the future than they have in the past, but they are likely to remain a sidelight. Indeed, some of the problems that plagued the recent effort to amend the Federal Rules may have been due to the heavy load of proposals on the Advisory Committee's plate, many of which were controversial and all of which vied for a finite amount of time for study, reflection, and discussion. ${ }^{356}$

The probable distribution of the rulemakers' workload in the future does not justify a major effort to secure relevant international expertise among their number, particularly since there are more pressing issues of representativeness. ${ }^{357}$ At the same time, however, revising the lists of those notified of proposed Federal Rules will not ensure that such expertise is effectively communicated and considered.

It will help in the future if the rulemakers understand that the executive branch is not a monolith and that differences of opinion are possible within, as well as between, agencies and departments. Such understanding might have prevented members of the Advisory Committee from imputing a change of

353. See, e.g., Burbank, supra note 255, at 715-19; Burbank, supra note 76, at 1934-41.

354. In ensuring such participation, it would render moot the very difficult question whether a Federal Rule of Civil Procedure can supersede a treaty. See 28 U.S.C. \& 2072(b)(1988); Burbank, supra note 72 , at 1488-90. Recently, a federal district court has even drawn in question the received wisdom that a statute can supersede a treaty. See Gouveia v. Vokes, 800 F. Supp. 241 (E.D. Pa. 1992).

355. See 28 U.S.C. $\$ 2072$ (1988). In establishing the Commission and Advisory Committee on International Rules of Judicial Procedure, Congress was equally concerned about improvements in state and federal tribunals. See Act of Sept. 2, 1958, Pub. L. No. 85-906, \& 2, 72 Stat. 1743, quoted supra text accompanying note 39 .

356. The 1993 amendments to the Civil Rules included controversial changes to Rule 11 and Rule 26. See Hughes, supra note 118 , at 5-8, 10 .

357. See Laura A. Kaster \& Kenneth A. Wittenberg, Rulemakers Should Be Litigators, NAT'L L.J., Aug. 17, 1992, at 15. 
position or reactiveness to comments the timing of which was in part a function of late notice to the State Department. ${ }^{358}$

Separate mailings to concerned departments and agencies can solve the problem of late notice, but they cannot solve the problem the rulemakers face when they confront, as they have recently, conflicting positions. One solution to that problem is to reduce conflicts by requiring executive branch comments on proposed Federal Rules to be coordinated and cleared in a manner similar to comments on proposed legislation. ${ }^{359}$ But even if the process works for legislation, it is doubtful that it should be extended to an arena in which no ultimate legislative activity is contemplated and thus the risks of muting or submerging one agency's or department's concerns may be unduly high.

Assuming that executive branch agencies and departments will remain free to comment separately on proposed Federal Rules, it is not appropriate for the rulemakers simply to discount criticism because it is not unanimous. It is possible to evaluate comments according to the perspective from which they are made. When, for example, a litigating agency comments on a proposal having international implications, it is fair to assume that it does so with considerable self-interest. The State Department lacks such direct self-interest, and it is above all charged with responsibility for this country's foreign relations. The comments of the State Department reflecting that responsibility deserve far more weight from the rulemakers in the future than they have received in the recent past.

For its part, the State Department should improve its method for formulating and communicating comments on proposed Federal Rules. It cannot safely rely on another department, which may have inconsistent views. ${ }^{360}$ Moreover, the Office of the Assistant Legal Adviser for Private International Law cannot easily perform the task given its current workload. The Secretary's Advisory Committee on Private International Law is not necessarily well-suited for such a specialized mission. ${ }^{361}$ It could, however, create a standing study group for the purpose of evaluating proposed Federal Rules and helping the Department prepare comments.

The proposed study group could perform useful services in addition to evaluating proposed Federal Rules. It could monitor experience under existing treaties, federal legislation, Federal Rules, and state provisions that relate to international civil litigation, as well as suggest reforms. In so doing, the group would continue the work of the Commission and Advisory Committee on International Rules of Judicial Procedure.

358. See supra text accompanying notes $142,166-67,344$.

359. See Office of Management and Budget Circular No. A-19 (rev. 1979).

360. See, e.g., Executive Branch Comments, supra note 106; Pfund, supra note 128, at 160-61.

361. See Nadelmann, supra note 48 , at 322; Pfund, supra note 1 , at 168. 


\section{B. Treatymaking and Interpretation}

The United States has come a long way since joining the Hague Conference in 1964. A well-developed structure is in place for advising the State Department on treaty proposals and for formulating and negotiating U.S. positions on matters of private international law. The United States has emerged from a period when there was concern that the failure to ratify treaties would imperil its effective participation in international lawmaking. ${ }^{362}$ We are no longer in a rush to conclude treaties, but neither are we paralyzed at the stage of national commitment. More public resources should be devoted to the enterprise, but the basic structure appears sound. Recent experience, however, suggests some steps that may be helpful in the future.

I have argued that the major weakness of the Supreme Court's decisions interpreting the Service and Evidence Conventions reposes not in the Court's treaty interpretations narrowly viewed, but in language that exalts domestic law, particularly the Federal Rules of Civil Procedure, and suggests an unwillingness to subordinate or adjust such law to the requirements of a treaty. ${ }^{363}$ I have also argued that, given the domestic ratification histories of those treaties, the Court's posture is understandable but that it has had a baneful effect on subsequent domestic lawmaking initiatives. ${ }^{364}$ Moreover, I have attempted to discriminate between unilateral domestic lawmaking that faithfully and appropriately advances the policies of a treaty and lawmaking that either subverts treaty policies or is an unjustifiable giveaway, both of which undermine our international bargaining position. ${ }^{365}$

If, as I believe, the United States will be required to compromise more in the future than it has (or has been willing to acknowledge) in the past when concluding treaties on aspects of procedure in international civil litigation, it is vitally important that the negotiators understand the compromises and fully and accurately describe them in the ratification process.

Just as the federal rulemaking process should more systematically and thoughtfully incorporate the views and perspectives of the State Department, the State Department should insure that its processes, in particular for study groups, require consultation with the rulemakers on matters proposed for international agreement that are addressed in the Federal Rules. ${ }^{366}$ Moreover, some similar mechanism should be in place to ensure understanding of the ramifications of possible treaty provisions for state procedural law.

Assuming the negotiators understand the extent to which a treaty signed on behalf of the United States derogates from domestic law, it should be easy for

362. See Pfund, supra note 1 , at $178-81$.

363. See supra text accompanying notes 196-207, 234-35, 259-62, 279-81, 309.

364. See supra text accompanying notes 279-86.

365. See supra text accompanying note 295; Burbank, supra note 72 , at 1480.

366. Effective consultation will depend upon the group consulted and timing. It is not enough to seek (or receive) blessing from the Judicial Conference after a treaty has been negotiated. See, e.g., 1967 SENATE DOCUMENT, supra note 154, at 7. 
them accurately to describe those matters in the ratification process. There may be reluctance to make full disclosure out of concern that it will generate controversy, which according to traditional wisdom is the death of private international law treaties. ${ }^{367}$ Yet, such a strategy has potential costs in addition to the obvious. Courts and other domestic lawmakers have good reason to be reluctant to confer-unilaterally in their view-advantages that the Senate had no reason to think it had conferred. Moreover, an emphasis on the integrity of domestic law in treatymaking renders even modest compromises vulnerable to subsequent unilateral domestic lawmaking. Both phenomena weaken the standing of the United States in the international community.

If the cost of candor in the ratification process is the Senate's unwillingness to give its advice and consent to private international law treaties, the United States may need to rethink its approach to such treaties. Assuming that the United States's interests are more than the sum of the collective preferences of U.S. legal consumers, it should be willing to ratify a treaty, even in the face of domestic opposition, if that treaty represents, on the whole, a net improvement.

\section{$\mathrm{V}$}

\section{CONCLUSION}

It is ironic that, at a time when the premises of U.S. procedure are undergoing reexamination and some of the basic rules are changing, ${ }^{368}$ lawmakers should remain so attached to the integrity of domestic law and its export abroad through international civil litigation. A good part of the explanation lies in the fact of, and the attitudes that shaped, a long history of unilateral lawmaking and the correspondingly short history of international lawmaking in its shadow. Moreover, in the case of federal procedural law, since 1938 the integrity of domestic law has meant uniformity. Seeking to preserve domestic procedural uniformity renders the quest for international uniformity more difficult. Finally, even if isolationism is no longer a national trait, impatience and chauvinism surely are, and will remain so if lawmakers ignore foreign and international law.

If I am correct that we can no longer have our cake and eat it too, institutional changes of the sort I have recommended will not be sufficient to accommodate the new reality. Nor, for that matter, will a greater infusion of time and money to international lawmaking. We must be more willing than we have been to engage other legal systems seriously. Only by doing so will we be able to redefine success in international lawmaking, ${ }^{369}$ and thereby become members in fact, as well as in name, of the international legal community.

367. See, e.g., Pfund, supra note 1, at 180-81; Pfund, supra note 318, at 517-18.

368. See, e.g., Burbank, supra note 76; supra text accompanying note 356.

369. See supra text accompanying note 306 . 


\section{POSTSCRIPT}

Shortly before this Symposium issue was to be published, Professor Carrington and Judge Phillips wrote their article on "the interface of treaties and rules of procedure." 370 That, of course, is a subject treated in some detail in my article. ${ }^{371}$ In order not further to delay publication, I leave a detailed comparison of our views to interested readers. I now wish to make only three observations.

First, I am delighted that Professor Carrington and Judge Phillips agree with me that procedural law necessarily implicating this country's foreign relations should be made by Congress, not the Supreme Court exercising rulemaking power under the Enabling Act. ${ }^{372}$ They thus agree with me that, at the least, Congress should have been alerted to the potential ramifications of extending the waiver of service mechanism in amended Rule 4 to those who must be served abroad. ${ }^{373}$

Second, contrary to those authors' present recollection, ${ }^{374}$ the foreign relations implications of the proposed amendments to Rule 4 were the subject both of written comments and of testimony in $1990,{ }^{375}$ before foreign governments made their objections known and before the State Department was aware

370. J. Dickson Phillips \& Paul D. Carrington, Reflections on the Interface of Treaties and Rules of Procedure: Time for Federal "Long-Arm" Legislation, 57 LAW \& CONTEMP. Probs. 153 (Summer 1994).

371. See supra text accompanying notes 99-179, 189-207, 233-37, 263-64, 282-86, 295-98, 309-12, 32961.

372. Compare Phillips \& Carrington, supra note 370, at 154 ("It seems to these authors that the place to resolve any conflicts between the Executive's concerns in foreign relations and the courts' concern for even-handed civil justice is in Congress."), with supra text accompanying note 339 ("For procedural law of the sort under discussion-necessarily and obviously implicating U.S. foreign relations-the perspective of institutional authority does not support the current process of creating Federal Rules."), and supra text accompanying notes 347-48.

373. Compare Phillips \& Carrington, supra note 370, at 154 ("We regret that [flagging 'any doubtful matters for consideration by Congress'] was not the process followed with respect to the 1993 revision of Rule 4"), and id. at 157-58, with supra text accompanying note 351 ("it is a shame that the Committee did not take a similar approach to other controversial provisions in Rule 4 that necessarily and obviously implicate this country's foreign relations").

374. See Phillips \& Carrington, supra note 370 , at 157 ("As best we recall, only one objection to the proposed revision of Rule 4 was timely received."). 89.

375. See sources cited supra notes 118, 124 and accompanying text; Burbank, supra note 72, at 1485-

Although court rules relating to the manner of service do not normally present problems of validity, there is reason to doubt whether the Supreme Court has the power to act as if it were the Congress, and to bypass presidential assent, where service of process implicates the foreign trade or foreign policy interests of the United States .... [N]ot only has this country entered into two international service conventions since 1963, but events in the intervening years have demonstrated the sensitivity of service on foreign nationals.

Letter from Stephen B. Burbank to Committee on Rules of Practice and Procedure 1-2 (Mar. 14, 1990) (copy on file with author). 
of the proposal. ${ }^{376}$ In that regard, these recent rulemakers are true to form in acting as if the executive branch were a monolith. ${ }^{377}$

Third, Professor Carrington and Judge Phillips regard the waiver of service issue as a "tempest ... in a teapot" ${ }^{378}$ because of the Supreme Court's decision in Schlunk. ${ }^{379}$ For me, the argument only confirms that Schlunk has had a baneful effect on procedural lawmaking for international cases. ${ }^{380}$ Indeed, taken together with the authors' proposal for a federal statute generalizing the result in Schlunk, ${ }^{381}$ the argument suggests how far domestic lawmakers may go in unilaterally cancelling the concessions made in a treaty. ${ }^{382}$

376. See supra note 344 and accompanying text.

377. Compare Phillips \& Carrington, supra note 370 , at 153 ("Foreign relations are in the first instance the concern of the Executive Branch; it negotiates treaties. It also participates in court rulemaking through its representation on the Judicial Conference committees."), and id. at 156 ("The Executive Branch participated at every stage and supported the proposed revision of Rule 4 in the form in which it was sent to the Supreme Court in 1990."), with supra text accompanying note 358 ("It will help in the future if the rulemakers understand that the executive branch is not a monolith and that differences of opinion are possible within, as well as between, agencies and departments. Such understanding might have prevented members of the Advisory Committee from imputing a change of position or reactiveness to comments the timing of which was in part a function of late notice to the State Department."). Cf. Frank H. Easterbrook, The State of Madison's Vision of the State: A Public Choice Perspective, 107 HARV. L. REV. 1328, 1328-29 (1994) (inappropriate to treat U.S. government "as a single hierarchical institution").

378. Phillips \& Carrington, supra note 370 , at 157.

379. Volkswagenwerk Aktiengesellschaft v. Schlunk, 486 U.S. 694 (1988). Apart from the dubiety of the assertion as it relates to parties located in countries adhering to the Hague Convention, the authors neglect, here as elsewhere in their article, the foreign relations implications in countries, such as Switzerland, that are not parties to that treaty. See, e.g., supra text accompanying notes 119-23. Attention to that dimension would help the authors answer some of the questions they pose about the final version of amended Rule 4. See Phillips \& Carrington, supra note 370, at 157.

380. See supra text accompanying notes 233-37, 279-85, 295-98.

381. See Phillips \& Carrington, supra note 370 , at $157-58$. Of course, the authors' proposal is much broader than a means to effect service within the United States and thereby avoid the requirements of the Hague Service Convention. It would also authorize the federal courts to assert personal jurisdiction according to a federal amenability standard.

382. See supra text accompanying notes 122-24, 233-37. 